IFN Working Paper No. 1034, 2014

\title{
The Glass Ceiling in Politics: Formalization and Empirical Tests
}

\author{
Olle Folke and Johanna Rickne
}




\title{
The Glass Ceiling in Politics: Formalization and Empirical
}

\section{Tests*}

\author{
Olle Folke ${ }^{+}$and Johanna Rickne ${ }^{\psi}$
}

\begin{abstract}
There is a scarcity of women and minorities at the apex of political power. This paper formalizes the concept of the glass ceiling for political organizations and builds on previous research to suggest four testable criteria. A glass ceiling exists if women and/or racial minorities (1) are discriminated against in the organization's promotion process and (2) the discrimination increases in severity for the top levels of power and over an individual's career trajectory. We suggest a series of empirical tests for this phenomenon and apply them to longitudinal data on Swedish politicians. Results show that women face a glass ceiling, while minorities' career disadvantages are more severe at the earlier career steps (a "sticky floor").
\end{abstract}

Keywords: Glass ceiling, political careers, subnational politics, women and politics, supply of politicians, gender inequality, racial inequality

JEL codes: J45; J16; J21; H10

\footnotetext{
* Financial support from the Swedish Research Council and the Torsten and Ragnar Söderberg Foundation is gratefully acknowledged. We thank Diana O’Brien, and seminar participants at the Center for American Women of Rutgers University for helpful comments.

+ Columbia University, SIPA, and Research Institute for Industrial Economics; of2152@columbia.edu.

${ }^{\psi}$ Research Institute for Industrial Economics, and Uppsala Center for Labor Studies; Johanna.rickne@ifn.se.
} 
"A glass ceiling is a political term used to describe the unseen, yet unbreachable barrier that keeps minorities and women from rising to the upper rungs of the corporate ladder, regardless of their qualifications or achievements."

\section{Federal Glass Ceiling Commission, 1995}

There is an unequal distribution of political power in most contemporary democracies. Women make up 21.8 percent of the world's parliamentarians, but only 7.8 percent of its heads of government and 5.9 percent of its heads of state (UN Women 2014). Systematic data collection is lacking for racial and ethnic minorities, but previous research has documented a clear underrepresentation in parliaments (Bloemraad 2013), and casual inspection suggests a striking absence from top offices. These patterns constitute an important democratic deficit, and suggest that society may be drawing its leaders from an overly narrow pool of human talent. After all, citizens deserve to be led by the best person, not just the best (white) man, for the job.

This paper tests whether the lack of women and minorities in the upper levels of political organizations can be explained by a glass ceiling effect. This is done in two steps. First, we draw on research from different academic disciplines to clearly define the metaphor of the glass ceiling for the political sector and in terms of four testable criteria. Second, we explain and showcase how these criteria can be tested empirically in a case study of Swedish local political organizations.

Our paper extends the growing literature on the under-representation of women in political leadership by shifting the focus from macro-systematic explanations of vertical 
inequality ${ }^{1}$ to party-level and micro-level explanations. Compared to most previous work, this entails a shift from country-level data to uniquely detailed panel data for politicians and the nomination decisions among these politicians by hundreds of local party groups. We add a novel perspective to the literature on the representation of racial and ethnic minorities by studying vertical inequality in the representation of these groups.

At the micro level, we emphasize that the concept of the glass ceiling represents a specific pattern of career disadvantages that can explain the lack of women and minorities at top positions (Baxter and Wright 2000a, 2000b; Cotter 2001; Federal Glass Ceiling Commission 1995; Feree and Purkayastha 2000; Martin 1991). There are two main features of this pattern. First, there must exist discriminatory barriers to the career advancement of women or racial minorities. In other words, the slower advancement of these groups must stem directly from their sex or minority status. If it instead stems from other factors - such as differences in work experience, other formal merits, or personal preferences - this is not consistent with a glass ceiling effect. The second requirement is that the discriminatory barriers grow thicker for positions that are higher up in the organizational hierarchy. If the disadvantages are more severe at the lower levels, this is not consistent with a glass ceiling but rather with a "sticky floor."

Fixing ideas about the glass ceiling effect for the political sector can provide more clarity to the academic literature and public debate. In the case of sex, the glass ceiling metaphor has been used as a blanket statement to simply describe the declining proportion of women at the top of political hierarchies (Jalalzai 2013; Jalalzai and Krook 2010; UN Women 2014). Scholarly work has overlooked the fact that the concept requires discriminatory promotions

\footnotetext{
${ }^{1}$ Including electoral systems, women- and minority-friendly cultural norms, differential access to education, control of financial capitals, or work opportunities (i.e., Inglehart and Norris 2003; Krook and O’Brien 2012; Reynolds 1999; Sanbonmatsu 2002; Siaroff 2000; Stokes 2005).
} 
between candidates with equal qualifications and more intense discrimination at higher organizational ranks (for examples of these omissions, see, e.g., Kenski and Falk 2004; Kropf and Boiney 2001; Thomas and Adams 2010; Palmer and Simon 2001, 2010; Trimble and Arscott 2003; Verge 2010). Our paper calls for a more stringent use of this metaphor as one specific and quite detailed explanation of vertical inequality.

Differentiating the glass ceiling effects from other drivers of vertical inequality is crucial from a policy standpoint. For example, it is commonly argued that an insufficient number of qualified candidates, the so-called pipeline problem, is causing women's under-representation in top political positions (Carroll and Strimling 1983; Carroll 1994; Darcy, Clark and Welch 1994; Herrick 1995; Kobayashi 2004; Norrander and Wilcox 1998; Rodriguez 2003). In this case, appropriate measures to foster a more equal division of power could include efforts to bolster recruitment and training, or even formal quotas. As these policies can deliver a richer pipeline of qualified candidates to entry-level positions, top positions would then become more equally divided over time. By contrast, inequality that is caused by a glass ceiling requires direct strategies that target the norms and practices that underpin discriminatory promotions. Improving the pool of qualified candidates is of little use if qualified women or minorities are systematically overlooked when candidates advance to the higher organizational levels.

In the case of local Swedish parties, we find that both women and minorities have a lower chance of promotion than ethnic majority men with equal qualifications. For women, these disadvantages are more severe at the top of the political hierarchy, which is consistent with the glass ceiling effect. For minorities, the disadvantages are worse at the lower level, which rather fits the metaphor of a sticky floor. Thus efforts to equalize the distribution of political power should include targeting discriminatory promotions at the appropriate stages of the political careers of these two groups. 


\section{Four Criteria for the Glass Ceiling in the Political Sector}

Our intent is to combine insights from research in other sectors with our understanding of the political sector in order to formalize the concept of the glass ceiling and derive testable criteria. A useful point of departure for this discussion is that discrimination is the foundation of the glass ceiling. It implies that a person's gender or minority status makes them less likely to be appointed to influential positions in an organizational hierarchy (Federal Glass Ceiling Commission 1995; Martin 1991). The glass ceiling is different from other forms of inequality because the obstacles for upward advancement increase in severity at the higher levels.

The most comprehensive operational definition of the glass ceiling is provided by Cotter et al. (2001). The authors break down the complicated metaphor into four criteria in order to facilitate their empirical testing. We modify the wording of their criteria and interpret the content to fit the political sector.

The first criterion is that there is a gender inequality in access to higher offices that is not explained by other job-relevant characteristics of the politician. In technical terms, there should exist a residual difference in the proportion of women or minorities in higher political offices after controlling for gender differences in experience, education, abilities, motivation, and other characteristics. This criterion reflects the idea of differential recruitment intensity for equal qualifications, which is already present in the political science literature, but in the context of recruitment for higher positions in the organization. For example, Norris and Lovenduski (1995) argue that a specific set of qualifications may be valued differently by party recruiters depending on the candidate's gender.

A caveat to the need to hold constant all job-relevant characteristics when we compare the probabilities of holding higher office across political minorities and majorities is that 
differences in these characteristics are likely endogenous to previous discrimination. For example, women or minorities may receive less mentoring from senior politicians simply because they are women or minorities. If so, mentoring is a mediator of the discrimination in recruitment to influential positions, and by controlling for this characteristic we risk masking some of the discrimination. In empirical work, potential measures of qualifications should be carefully scrutinized so that they do not mask the glass ceiling effect. Controlling for differences in qualifications that arise as an integral part of a discriminatory promotion process will hide the true extent of the potential discrimination. At the same time, failing to control for differences in career attainment that derive from true differences in productivity of preferences will erroneously attribute these differences to discrimination.

An individual's length of work experience in an organization plays a key role in the concept of the glass ceiling. For criterion 1, it is a crucial qualification that must be held constant. Comparing individuals with the same length of work experience eliminates the risk of confusing differential exit rates with differential promotion rates. This could be particularly important for the political sector, where research on women's political under-representation has emphasized the role of the "revolving door syndrome." Negative behavior from male colleagues or women's role as caregivers within the family have been found to push women to leave politics more quickly than men (i.e., Childs 2004; Sapiro 1982; Thomas 2002). For criterion 1 to hold, we should abstract from higher rates of exit among women and minorities that stem from these sources. Nevertheless, exits could also be endogenous to the glass ceiling. Women and minorities could lose career motivation in the face of discriminatory promotions and leak out of the political pipeline. In this circumstance, we should be aware that controlling for the length of experience would underestimate the true extent of that discrimination.

The second glass ceiling criterion is that the gender and racial inequality in appointments to influential positions is greater for more senior positions. This represents the metaphor of a 
ceiling that hinders upward movement and restricts access to offices above a certain level in the organization (Baxter and Wright 2000a; see also Albrecht, Bjorklund and Vroman 2003; Morgan 1998; Prokos and Padavic 2005). This criterion separates the glass ceiling effect from the idea of a "sticky floor," where discrimination makes it harder for minorities to advance beyond the entry level of an organization (e.g., Arulampalam, Booth and Bryan 2007; Kee 2005).

The empirical implications of the second criterion have been subject to scholarly debate. Earlier work argued that the criterion should correspond to increasing odds differentials for advancement to higher positions compared to mid-level positions (Baxter and Wright 2000a). A critique of this definition, which was subsequently acknowledged by Baxter and Wright (2000b), held that a constant disadvantage across levels should be sufficient. Feree and Purkayastha (2000) convincingly stated that from the view of the candidate, even a constant disadvantage at each career step would produce a cumulative (and thereby greater) disadvantage for the upper steps. In turn, this situation would create a pattern of a decreasing proportion of women and minorities, i.e., vertically increasing disadvantages at higher organizational levels, which is the hallmark of the glass ceiling. Cotter et al. $(2001,659)$ note that a constant disadvantage should be considered evidence of a glass ceiling, but that a growing inequality in odds ratios should makes us "even more confident that the glass ceiling exists."

\footnotetext{
${ }^{2}$ Another critique concerns unobserved qualifications. If women are subjected to a more stringent selection process (due to discrimination) as one moves up organizational hierarchies, women in the available pool of potential candidates for subsequent promotion may be increasingly more qualified than men in the pool along some unobserved dimensions. From this perspective, a constant (or even decreasing) chance of advancement would still represent more discrimination at the top of the hierarchy, as the pool of available women has become superior to the pool of available men (Feree and Purkayastha 2000).
} 
Criterion 2 requires the researcher to specify a ladder of political appointment for the empirical context at hand. Arguably, this is considerably less thorny than performing the same exercise for the corporate sector. Political systems and organizations around the world tend to have quite predictable and comparable promotion ladders that politicians climb over the course of a career (Fenno 1973; Hagevi 2010; Matthews 1969; Norris 1997). ${ }^{3}$

The third and fourth glass ceiling criteria disentangle inequality in representation at different levels in the political hierarchy from inequality in advancement into those higher levels (Cotter et al. 2001). The third criterion states that there are inequalities in the rates of advancement into higher offices, not merely in the proportion of gender and minority persons that is found to occupy those positions. Testing this criterion requires longitudinal data for the promotions (or non-promotions) of individuals over time, and not just cross-sectional information on the ratios of women or minorities at different organizational levels.

Criterion 3 addresses some weaknesses in cross-sectional estimations of inequalities in the probabilities of holding influential positions. First, the cross-sectional method fails to account for the fact that not all individuals enter the organization at the lowest level, and that majority men may be more likely to enter directly at higher levels. This produces a situation with an over-representation of majority men at these levels, especially when only persons with the same length of work experience are compared. But this situation is not the result of discriminatory promotions, which is the idea of the glass ceiling. The direct comparison of actual promotions according to criterion 3 is designed to sidestep this concern.

Another weakness of the cross-sectional approach, which is not discussed by Cotter et al. (2001), is that a lower proportion of women and minorities in top positions may be the consequence of a "class cliff" rather than a "glass ceiling" (Ryan and Haslam 2005, 2007;

\footnotetext{
${ }^{3}$ See also Blondel 1987; Davis 1997; Kobayashi 2004.
} 
O'Brien 2014). If women and minorities have shorter tenures in their top positions (i.e., they fall off the glass cliff), this will produce small proportions of women and minority leaders, but not because of discriminatory promotions. Again, longitudinal comparisons of inequalities in actual promotions rules out this alternative explanation.

The fourth and final criterion is that gender or racial inequalities increase over the course of a career, and more so for higher positions in the organization. For majority and minority groups that enter the organization at the same hierarchical position, career paths should be more similar at first but then diverge over time as women and minorities are prevented from advancing up the hierarchy of positions.

Criterion 4 specifically states that the glass ceiling should become more salient over the career trajectory. If we only observe a difference in the probability of promotions for a given length of experience, as in criterion 3 , this difference could be driven by unequal chances of promotion among newcomers in the organization. This situation fails to capture the idea of a growing inequality during a career trajectory.

Criterion 4 specifically requires that the differential returns of experience are larger for more influential positions. If we imagine a man and a woman starting out together at the entry level, the probability that they will reach the middle level after a couple of election periods should be more similar than the differential between a man and a woman who start at the middle level and seek advancement to the top. If a glass ceiling exists, we should observe a more dramatic career divergence for the same length of experience for the top positions in the hierarchy compared to the less influential positions. 


\section{Case Study and Data: Swedish Municipal Politics}

To illustrate how to test criteria 1-4 for the existence of a glass ceiling in the political sector, we analyze panel data for Swedish municipal politicians. Our dataset contains all elected politicians in seven elections, 1988-2010, in each of Sweden's 290 municipalities. Each of these councils has between 31 and 101 members who are elected via a flexible list proportional representation (PR) system with one preferential vote allowed per voter.

The political power of the municipality is concentrated in the council's board, which corresponds to the national-level government. Its chairperson is appointed by the largest party in the governing coalition after the general election, and the remaining board seats are distributed among all parties according to the number of seats they hold in the full assembly. Specific policy areas are dealt with in subcommittees, and the chair of each committee is appointed by the governing majority. Most municipal councils have seven subcommittees, including those for education, social work, and building permits and land use.

According to Swedish law, all political parties must submit their electoral ballots to the electoral authority and include the personal identification number of every politician on the list. Using this information, we requested Statistics Sweden to link every politician on every electoral ballot to yearly panel data on a host of socioeconomic variables from the administrative records for the full period (1988-2010). This data is not self-reported, and is therefore highly accurate and without missing values. It includes background variables such as educational attainment, age, occupation sector, and the birth year for every child of every politician.

Our two key socioeconomic characteristics are gender and minority status. Following Kymlicka (1995) and Bloemraad and Schönwälder (2013), the latter is defined as polyethnic minorities of immigrant origin, a measure that is well aligned with the Swedish political realities 
and views on minority representation in the public discourse and previous research (i.e., Dahlstedt 2004; Soininen and Etzler 2006; Soininen 2011). We construct a binary indicator of minority status that takes a value of 1 if the politician or either parent was born abroad. This indicator captures the brunt of immigration to Sweden, including the earliest wave of labor migration in the decades after the Second World War and of which the geographically dispersed Finns, Romani, and Jews have attained the status of national minorities. Table S.4 in the Supporting Information shows the distribution of regions of origin of first-generation immigrants and the parents of the second-generation immigrants in our sample. Our definition of minorities does not include the indigenous Sami people, thought to number roughly 35,000 individuals, who reside in Sweden's northern region and have a separate political assembly called Sametinget. Nor does it include the fourth and final national minority group, the Tornedalians, who immigrated long before other groups, in the $14^{\text {th }}$ century, and who reside mainly in the Torne Valley region near the Finnish border. This group is thought to number roughly 50,000 individuals. ${ }^{4}$ Following Bloemraad and Schönwälder (2013) we will refer to the discrimination of these minority individuals as "racial discrimination". With this we do not refer to genetical differences but rather to racialization of these groups in society.

To map local party organizations' internal hierarchies, we use survey data on the exact position(s) of influence that each politician was appointed to after the two most recent elections, in 2006 and 2010. This information comes from a mandatory survey sent to each municipality by Statistics Sweden six months after each general election. We operationalize the political hierarchy as a three-level organization:

\footnotetext{
${ }^{4}$ Similar to France or Belgium, Sweden does not collect data on “ethnicity” apart from a person's country of birth, and a person is considered Swedish without any other distinction if he or she has attained Swedish citizenship (c.f. Lépinard 2013).
} 
(a) Level 1-elected politicians: those who are elected but do not belong to the group of top and mid-level politicians.

(b) Level 2-mid-level chairs: those who are appointed as the chair of a subcommittee or municipal council, but not to the municipal council board.

(c) Level 3-top chairs (mayors): those who are appointed to chair the municipal council board.

Using this operationalization requires that we limit our data sample to the largest political party in the governing majority in each municipality and election period. These parties appoint the majority of the subcommittee chairs (L2) and are guaranteed to appoint the chair of the council board (L3). Within these parties there is hence a clear organizational ladder ranging from lower to higher appointments. Our three-level political hierarchy is supported by politicians' own rankings (Gilljam, Karlsson and Sundell 2010) and research on the power structure in municipal politics (Montin 2007). It also mirrors the work time and pay received by the politicians, from largely honorary at the entry level to full-time pay at the top level. Section S.1 in the Supporting Information provides a more detailed discussion of our operationalization and the alternative of also taking into account the vertical inequality between more or less powerful subcommittees (Baekgaard and Kjaer 2012; Carroll 2008; Yule 2000). Although there is a clear gender division of labor across these committees (see Table S.1), we agree with Wide (2011) that the standard approach to characterizing committee power is not appropriate in the Swedish municipal context. Municipalities' main areas of political authority coincide largely with traditional "female" and "soft" issue areas, such as child and elderly care, which makes these committee chairs (at least) as politically important as for example the chairs of the budgetary or technical committees. 
Figure 1 illustrates a pattern of vertical inequality for women and minorities in our sample by showing the share of each group at each of the three hierarchical levels described above. It is strikingly clear that the proportions of both women and minorities drop as we move across the three levels of appointments.

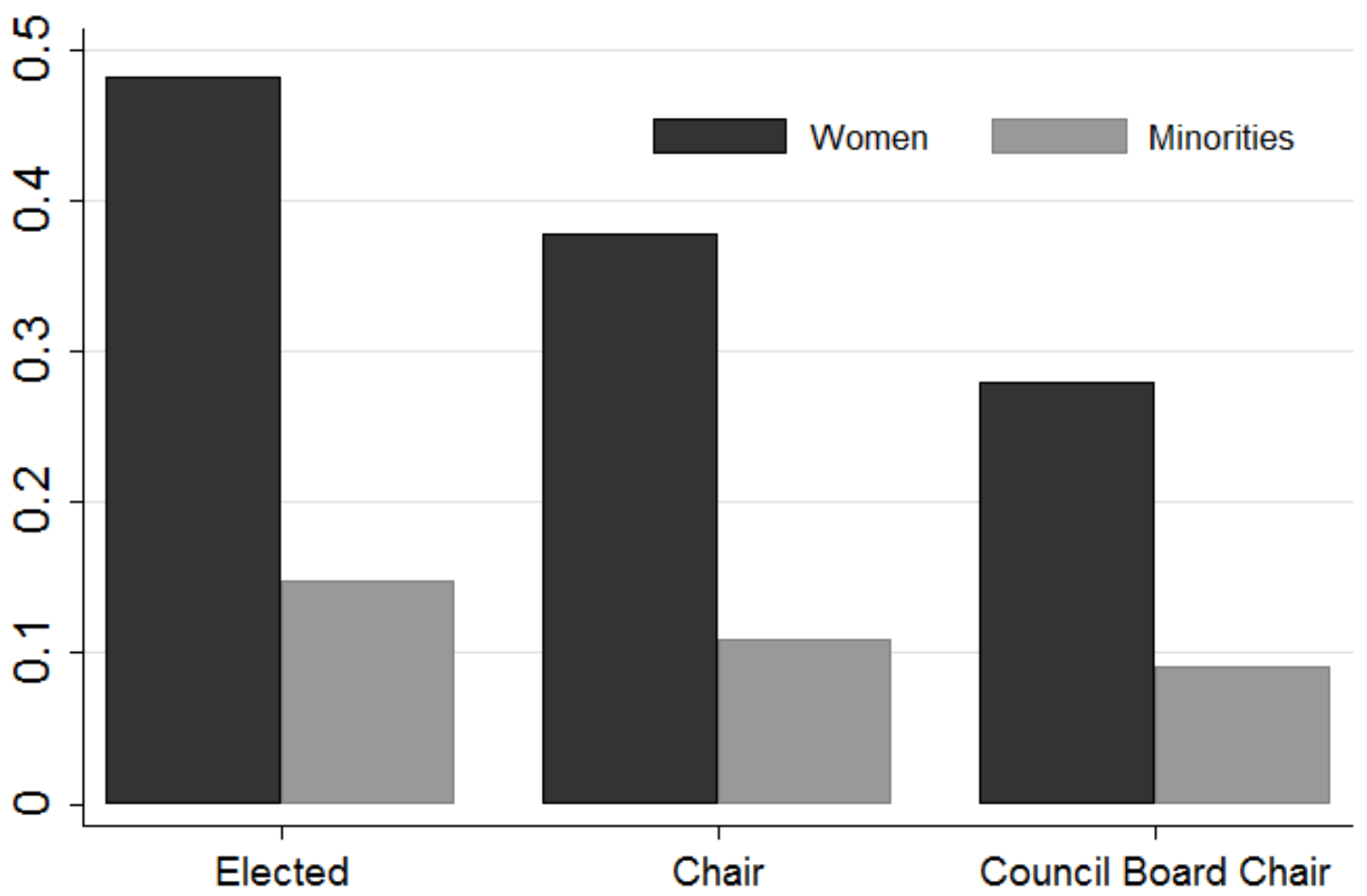

Figure 1. Proportion of women and minorities across three levels of political appointments in Swedish municipal political parties

The sample used in the analysis comprises politicians from the largest majority parties and covers 34 percent of the universe of elected politicians in the Swedish municipalities. The proportion of women is highly similar in the full dataset (0.44) and in the sample (0.45). Table S.2 in the Supporting Information provides a thorough descriptive comparison of the politicians in the sample and in the full dataset. The table shows the gender and racial differences in characteristics, which are highly similar in the sample and the full dataset. In both, women and minorities are younger and more likely to have tertiary education compared to ethnic majority 
men. Minority politicians are highly over-represented among politicians with short political tenures, while women are not.

As expected, our dataset comprised of the largest party in the governing coalition has an over-representation of the large political parties. In our sample, Social Democrats account for 46 percent and Conservatives for 32 percent of the observations, compared to 39 and 24 percent, respectively, in the full dataset. The sample is, however, quite balanced in terms of the political blocs. The ruling parties come from the center-right bloc in 53 percent of the municipalities, and from the left bloc in 47 percent of the cases. ${ }^{5}$

\section{Measuring Qualifications for Political Appointments}

It is an empirical challenge to measure all relevant and job-related qualifications for higher political appointments. As discussed above, the measures should not be endogenous to previous discrimination and should reflect all relevant job-related characteristics.

The length of job experience is a key qualification for top positions in any sector. As noted above, climbing the career ladder inside the organization by consecutive promotions over time is the standard way to reach the top posts in most political systems around the world (Fenno 1973; Matthews 1969 Norris 1997; Hagevi 2010). ${ }^{6}$ Previous experience in political office is a common measure of a politician's quality, in particular in studies of U.S. politics (e.g., Cox and

\footnotetext{
${ }^{5}$ The full breakdown of parties is: Social Democrats 45.8 percent, Left Party 0.7 percent, Conservative Party 32.34 percent, Center Party 17.66 percent, Liberal Party 1.57 percent, and Christian Democrats 1.92 percent.

${ }^{6}$ Arguably, seniority is less important in some regions of the world, most importantly in Latin America (Escobar-Lemon and Taylor-Robinson 2005; Heath, Schwindt-Bayer and Taylor-Robinson 2005; Morgenstern and Nacif 2002; Schwindt-Bayer 2005).
} 
Katz 1996; Hirano and Snyder 2013). Skills improve over time as politicians develop taskspecific human capital such as political bargaining and coalition building. ${ }^{7}$

We measure experience as the number of previous terms that a politician has served in the municipal assembly. Because the earliest available year in our data is 1988 , we truncate the variable at a maximum of five election periods. For comparability, we extend the sample back to 1988 for politicians elected in 2006 and back to 1991 for those elected in 2010. All periods are included in the count, irrespective of whether they are consecutive or not.

When we chose additional measures of qualifications, we should keep in mind that the very notion of a "qualified candidate" is not objective. Women and minorities could hold different life experiences, skills, and personality traits that are not considered equally valuable merits by party elites. We depart from the status quo of characteristics that are generally used to capture politician quality and that have traditionally helped male candidates get into power: education level, experience in national parliament, age, and employment sector (SchwindtBayer 2011). In the Supporting Information section we explain our choice of measures based on previous research and give a detailed description of the variables.

Even though our data is of uniquely good quality when it comes to measuring qualifications, important factors remain unobserved in the baseline analysis. For women in particular, prioritizing family care obligations over political career concerns can jeopardize productivity in office and the development of skills and ambitions for seeking a higher position. In our baseline analyses we follow Cotter et al. (2001) and excluding family-related variables from the set of baseline qualification controls. To address the concern of family priorities, our

\footnotetext{
${ }^{7}$ Some studies expand the definition of political experience to include bureaucratic appointments (Franceschet and Piscopo 2012), while others only count experience in the same legislative body (Ferraz and Finan 2011).
} 
robustness checks then ensure that our baseline results are robust to excluding all politicians who have children.

Other unobserved variables include political ambitions and effort. We can, however, use survey data to inspect gender and racial differences in these dimensions. Figures S.1 and S.2 in the Supporting Information show the gender and racial distributions of politicians' desired future tenure, answering the question "for how long to you wish to remain an elected representative?" These figures show no differences in the distribution across gender and minority status. Table S.2 shows gender and racial differences in self-reported levels of political effort across 14 policy areas. The results show that racial and gender differences are negligible in size among politicians on our three levels of political appointments (L1-L3). With an 80 percent response rate in the underlying survey, these descriptive results do not indicate the existence of a severe bias in our baseline findings based on gender or racial differences in ambitions or effort.

Finally, our analysis lacks data on job-relevant qualifications in the form of positions of trust in the local party administration, or previous or current appointments in youth organizations, civil society, etc. We also fail to control for politicians' receipt of preferential votes. Because these votes are strongly and positively correlated with appointments, the control is highly endogenous to promotions and would bias our results toward a rejection of the glass ceiling criteria (for further discussion, see Section S.1 in the Supporting Information).

\section{Empirical Methodology and Results}

This section outlines the methodology for testing our four glass ceiling criteria and presents the results of each estimation from our case study of Swedish municipalities. 


\section{Criterion 1: there are gender and racial inequalities in access to higher offices that are not explained by other job-relevant characteristics of the politician.}

We test the first criterion by estimating the following regression equation

$$
Y_{i t}=a_{i t}+\beta_{1} w_{i}+\beta_{2} m_{i}+\lambda^{\prime} E_{i t}+\eta^{\prime} Q_{i t}+\gamma_{p t}+\varepsilon_{i t},
$$

where the outcome variable, $Y_{i t}$, is a binary indicator for holding a position of influence. The first variable, $w_{i}$, is the binary indicator for being a woman. The estimate for this indicator, $\beta_{1}$ , captures the difference in the probability of holding a position of influence between the average woman and the average man. The second variable, $m_{i}$, is the binary indicator for minority status and its estimate, $\beta_{2}$, captures the probability that the average minority representative holds a position of influence compared to the average majority representative. To hold qualifications for higher office constant, the regression includes a variable vector $E_{i t}$ that contains the five binary indicators for the number of previous periods in office. It also includes the vector $Q_{i t}$ that contains all other qualification control variables.

Finally, we add fixed effects for each party group interacted with fixed effects for each election period, $\gamma_{p t}$. This controls for the fact that the average probability of holding a position of influence will differ both across municipalities and within the same municipal ruling party and over time, for example due to variation in the size of the party group. By including a dummy variable for each party group and year, we ensure that our estimated inequalities rely on differences within the same party group and in the same election period.

We estimate Equation (1) using ordinary least squares (OLS) and logit, which gives us estimates of both the absolute and relative magnitudes of the potential gender and racial 
inequalities. The logit estimation addresses the concern of biased estimations in OLS regressions with binary outcome variables.

The results are presented in Table 1. Columns 1 through 3 examine inequalities in holding any type of chair position, either a mid- or top-level positions. In columns 4 through 6 we estimate the inequalities in holding the top position only. For each outcome we present the results without any control variables (columns 1 and 4), adding the control variables for political experience (columns 2 and 5), and adding both the control variables for experience and other qualifications (columns 3 and 6). The table's upper pane shows the OLS results and the lower pane shows the logit results.

Table 1. Gender and minority disadvantages in holding any chair position, or holding the council board chair position, for given length of political experience and other qualifications.

$$
\begin{array}{cc}
\text { Any chair position }(\mathrm{L} 2+\mathrm{L} 3)=1, & \text { Council board chair }(\mathrm{L} 3)=1, \\
\text { otherwise } 0 & \text { otherwise } 0
\end{array}
$$

\begin{tabular}{|c|c|c|c|c|c|c|}
\hline & 1 & 2 & 3 & 4 & 5 & 6 \\
\hline \multicolumn{7}{|l|}{ Pane A: OLS } \\
\hline Woman & $\begin{array}{c}-10.77 * * * \\
(0.98)\end{array}$ & $\begin{array}{c}-8.05 * * * \\
(0.94)\end{array}$ & $\begin{array}{c}-9.57 * * * \\
(1.04)\end{array}$ & $\begin{array}{c}-4.13 * * * \\
(0.52)\end{array}$ & $\begin{array}{c}-2.99 * * * \\
(0.53)\end{array}$ & $\begin{array}{c}-3.83 * * * \\
(0.59)\end{array}$ \\
\hline Minority & $\begin{array}{c}-8.14 * * * \\
(1.45)\end{array}$ & $\begin{array}{c}-4.15 * * * \\
(1.37)\end{array}$ & $\begin{array}{c}-5.47 * * * \\
(1.40)\end{array}$ & $\begin{array}{c}-1.67 * * \\
(0.74)\end{array}$ & $\begin{array}{l}-0.16 \\
(0.73)\end{array}$ & $\begin{array}{l}-1.30^{*} \\
(0.72)\end{array}$ \\
\hline Observations & 8,883 & 8,883 & 8,823 & 8,844 & 8,844 & 8,784 \\
\hline \multicolumn{7}{|l|}{ Pane B: Logit } \\
\hline Woman & $\begin{array}{c}-0.52 * * * \\
(0.05)\end{array}$ & $\begin{array}{c}-0.43 * * * \\
(0.05)\end{array}$ & $\begin{array}{c}-0.53 * * * \\
(0.06)\end{array}$ & $\begin{array}{c}-0.70 * * * \\
(0.09)\end{array}$ & $\begin{array}{c}-0.54 * * * \\
(0.10)\end{array}$ & $\begin{array}{c}-0.69 * * * \\
(0.11)\end{array}$ \\
\hline Minority & $\begin{array}{c}-0.41 * * * \\
(0.08)\end{array}$ & $\begin{array}{c}-0.24 * * * \\
(0.08)\end{array}$ & $\begin{array}{c}-0.32 * * * \\
(0.08)\end{array}$ & $\begin{array}{c}-0.32 * * \\
(0.16)\end{array}$ & $\begin{array}{l}-0.05 \\
(0.16)\end{array}$ & $\begin{array}{l}-0.25 \\
(0.16)\end{array}$ \\
\hline Observations & 8,883 & 8,883 & 8,823 & 8,844 & 8,844 & 8,589 \\
\hline $\begin{array}{l}\text { Experience } \\
\text { Other qualifications }\end{array}$ & & yes & $\begin{array}{l}\text { yes } \\
\text { yes }\end{array}$ & & yes & $\begin{array}{l}\text { yes } \\
\text { yes }\end{array}$ \\
\hline
\end{tabular}

Notes: Fixed effects for municipalities interacted with fixed effects for election periods are included in all specifications. Robust standard errors in parentheses. * significant at 10\%; ** significant at 5\%; *** significant at $1 \%$. Experience control variables are five binary indicators for $1-5$ periods of previous experience. Other qualification controls include dummy variables for six education levels, dummy variables for five age categories, dummy variables for ten occupation sectors, and a dummy variable for previous experience as a parliamentarian. 
The results in Table 1 clearly support criterion 1 for a glass ceiling for women. Holding experience and other qualifications constant, the average woman is about 10 percentage points, or 52 percent, less likely to hold a chair position than the average man. The corresponding disadvantage in holding the top position is 4 percentage points, or 71 percent.

The results are less conclusive regarding the glass ceiling for minorities. For the mid-level position we find a negative and significant estimate, showing that the average minority representative is 5 percentage points, or 32 percent, less likely to hold a chair position than the average majority representative. For reaching the top position (Columns 4-6), the point estimates suggest a disadvantage of 1 percentage point, or 25 percent, but after including all the control variables only the OLS estimate is statistically significant, and then only at the 10 percent level.

Comparing the results for the regression specifications with and without controls for qualifications delivers some additional insights. Lower levels of experience account for roughly one-fourth of the observed inequality in holding both the mid-level and top positions for women and at least half of the inequality for immigrants. Adding the control variables for age, education, and occupation sector gives larger point estimates (i.e., stronger qualifications) for both women and minorities.

Criterion 2: the inequality in holding influential positions should be more pronounced for higher political offices than for lower offices.

To test criterion 2 we follow Baxter and Wright (2000a) and compare inequalities in the probability of holding the higher of two "adjacent" positions in the organizational hierarchy. In our context of three hierarchical levels, we hence make two comparisons. The first specification excludes politicians at the top level and examines the probability of holding a mid-level chair 
position instead of an entry-level position (L2 vs. L1). The second specification excludes the entry-level politicians and compares the probability of holding a top position instead of a midlevel position (L3 vs. L1).

We again estimate Equation 1 and present the results in Table 2. The outcome variables are binary indicators for holding the higher of the two positions in our pair-wise comparisons. Our estimates of interest capture the gender $\left(\beta_{1}\right)$ and racial $\left(\beta_{2}\right)$ inequalities in the probability of holding a higher position and of having equal qualifications. Support for criterion 2 requires statistically significant inequalities that are either of constant size across the two levels, or larger for the top level than for the middle level.

Table 2. Gender and minority inequalities in holding a mid-level chair position vs. being elected, and in holding a council board chair position vs. holding a mid-level chair position.

\begin{tabular}{|c|c|c|c|c|c|c|}
\hline & \multicolumn{3}{|c|}{$\begin{array}{l}\text { Mid-level chair position }=1 \\
\quad \text { elected politician }=0\end{array}$} & \multicolumn{3}{|c|}{$\begin{array}{l}\text { Top-level chair position }=1 \\
\text { Mid-level chair position }=0\end{array}$} \\
\hline & 1 & 2 & 3 & 4 & 5 & 6 \\
\hline \multicolumn{7}{|l|}{ Pane A: OLS } \\
\hline Woman & $\begin{array}{c}-8.24 * * * \\
(1.01)\end{array}$ & $\begin{array}{c}-6.53 * * * \\
(0.96)\end{array}$ & $\begin{array}{c}-7.75^{* * *} \\
(1.07)\end{array}$ & $\begin{array}{c}-6.94 * * * \\
(2.18)\end{array}$ & $\begin{array}{c}-6.18 * * * \\
(2.16)\end{array}$ & $\begin{array}{c}-7.64 * * * \\
(2.26)\end{array}$ \\
\hline Minority & $\begin{array}{c}-7.05 * * * \\
(1.40)\end{array}$ & $\begin{array}{c}-3.86 * * * \\
(1.35)\end{array}$ & $\begin{array}{c}-4.46 * * * \\
(1.38)\end{array}$ & $\begin{array}{l}-0.04 \\
(3.36)\end{array}$ & $\begin{array}{c}1.54 \\
(3.22)\end{array}$ & $\begin{array}{l}-0.84 \\
(3.08)\end{array}$ \\
\hline Observations & 8,273 & 8,273 & 8,225 & 2,633 & 2,633 & 2,608 \\
\hline \multicolumn{7}{|l|}{ Pane B: Logit } \\
\hline Woman & $\begin{array}{c}-0.44 * * * \\
(0.05)\end{array}$ & $\begin{array}{c}-0.38 * * * \\
(0.05)\end{array}$ & $\begin{array}{c}-0.46^{* * *} \\
(0.06)\end{array}$ & $\begin{array}{c}-0.37 * * * \\
(0.11)\end{array}$ & $\begin{array}{c}-0.33 * * * \\
(0.11)\end{array}$ & $\begin{array}{c}-0.46 * * * \\
(0.12)\end{array}$ \\
\hline Minority & $\begin{array}{c}-0.40 * * * \\
(0.08)\end{array}$ & $\begin{array}{c}-0.24 * * * \\
(0.08)\end{array}$ & $\begin{array}{c}-0.27 * * * \\
(0.09)\end{array}$ & $\begin{array}{l}-0.00 \\
(0.17)\end{array}$ & $\begin{array}{c}0.08 \\
(0.17)\end{array}$ & $\begin{array}{l}-0.09 \\
(0.18)\end{array}$ \\
\hline Observations & 8,083 & 8,083 & 8,031 & 2,609 & 2,609 & 2,531 \\
\hline Experience & & yes & yes & & yes & yes \\
\hline Other qualifications & & & yes & & & yes \\
\hline
\end{tabular}


The results show a large and statistically significant inequality between women and men in the probability of holding the higher of the two positions in both of our pair-wise comparisons. Both inequalities are of similar size, which means that criterion 2 finds support in the data. The average woman has an approximately 7.5 percentage point, or 46 percent, lower probability of holding the more influential position. For a woman at the entry position, this constant disadvantage in both steps translates into a larger cumulative disadvantage in reaching the top.

The results for minority representatives do not support criterion 2 . The inequality between minority and majority representatives is substantially larger, both in absolute and relative terms, for the lower pair of adjacent positions. Holding qualifications constant, the disadvantage in holding a mid-level position compared to an entry-level position is 4 percentage points, or 27 percent. By contrast, the estimated disadvantage in holding the top position compared to the mid-level position is close to zero and not statistically significant.

Criterion 3: An inequality exists for the probability of advancing to a higher level, not only in the proportion of women or minorities at those levels.

The third criterion adds a dynamic element to the analysis. We examine the pattern of promotions between the 2006 and 2010 elections. Equation (1) is estimated with a binary outcome variable that takes a value of 1 for politicians who moved to a higher level in 2010 compared to 2006, and 0 for those who remained at the same level.

Separate regressions are estimated for promotions from level 1 to level 2 (Table 3, columns 1-3) and from either level 1 or level 2 to level 3 (columns 4-6). The estimate of $\beta_{1}$ captures the average woman's promotion probability relative to the average man's. The estimate of $\beta_{2}$ captures the same inequality between the average minority and majority representatives. 
In both cases qualifications are again held constant, and in the regression for the top position we also condition on the current position. By including the latter control, we make sure that our estimates of interest do not capture an over-representation of majority men at the mid-level position where the promotion probability for the top position is greater than that from the entry level.

In this analysis, our data sample is restricted to political parties that were the largest majority party in both 2006 and 2010. The inclusion of party group fixed effects also means that we drop all groups that had a constant outcome variable across both years, i.e. the distribution of positions remained the same.

Table 3 shows support for criterion 3 for women but not for minorities. For women, our preferred specification (column 3) shows that the average woman has a 45 percent lower probability of being promoted from level 1 to level 2 compared to the average man, and a 61 percent lower probability of being promoted to council board chair from either level 1 or level 2. Although the latter estimate lacks statistical precision and should be interpreted with some caution, the two estimates together imply that women face promotion disadvantages that fit the metaphor of the glass ceiling.

For minorities we find smaller estimates for promotion disadvantages than for women, and the estimates have large standard errors. The combination of these two factors means that none of the estimates is close to statistically significant at any conventional level. Thus we do not find empirical support for criterion 3 in the case of minorities. 
Table 3. Gender and racial inequality in transitions to positions of influence between 2006 and 2010.

\begin{tabular}{|c|c|c|c|c|c|c|}
\hline & \multicolumn{3}{|c|}{$\begin{array}{l}\text { Promotion from } \\
\text { L1 to } \mathrm{L} 2=1, \\
\text { No promotion }=0\end{array}$} & \multicolumn{3}{|c|}{$\begin{array}{c}\text { Promotion from } \\
\text { L1 or L2 to L3 }=1 \\
\text { No promotion }=0\end{array}$} \\
\hline & 1 & 2 & 3 & 4 & 5 & 6 \\
\hline \multicolumn{7}{|l|}{ Pane A: OLS } \\
\hline Woman & $\begin{array}{l}-3.99 \\
(2.47)\end{array}$ & $\begin{array}{l}-4.19 * \\
(2.49)\end{array}$ & $\begin{array}{c}-6.02 * * \\
(2.83)\end{array}$ & $\begin{array}{l}-1.73 \\
(2.21)\end{array}$ & $\begin{array}{l}-2.29 \\
(2.18)\end{array}$ & $\begin{array}{l}-3.32 \\
(2.12)\end{array}$ \\
\hline Minority & $\begin{array}{l}-1.19 \\
(3.31)\end{array}$ & $\begin{array}{l}-1.40 \\
(3.39)\end{array}$ & $\begin{array}{l}-3.05 \\
(3.52)\end{array}$ & $\begin{array}{l}-0.90 \\
(2.75)\end{array}$ & $\begin{array}{l}-1.22 \\
(2.83)\end{array}$ & $\begin{array}{l}-2.46 \\
(2.83)\end{array}$ \\
\hline L2 & & & & $\begin{array}{c}11.48 * * * \\
(2.58)\end{array}$ & $\begin{array}{c}12.30 * * * \\
(2.86)\end{array}$ & $\begin{array}{c}10.97 * * * \\
(2.78)\end{array}$ \\
\hline Observations & 1,160 & 1,160 & 1,157 & 787 & 787 & 784 \\
\hline \multicolumn{7}{|l|}{ Pane B: Logit } \\
\hline Woman & $\begin{array}{l}-0.27^{*} \\
(0.16)\end{array}$ & $\begin{array}{l}-0.29 * \\
(0.16)\end{array}$ & $\begin{array}{c}-0.44^{* *} \\
(0.18)\end{array}$ & $\begin{array}{l}-0.22 \\
(0.30)\end{array}$ & $\begin{array}{l}-0.29 \\
(0.30)\end{array}$ & $\begin{array}{l}-0.62 * \\
(0.34)\end{array}$ \\
\hline Minority & $\begin{array}{l}-0.09 \\
(0.22)\end{array}$ & $\begin{array}{l}-0.10 \\
(0.22)\end{array}$ & $\begin{array}{l}-0.22 \\
(0.24)\end{array}$ & $\begin{array}{l}-0.13 \\
(0.47)\end{array}$ & $\begin{array}{l}-0.17 \\
(0.48)\end{array}$ & $\begin{array}{l}-0.40 \\
(0.56)\end{array}$ \\
\hline L2 & & & & $\begin{array}{c}1.24 * * * \\
(0.27)\end{array}$ & $\begin{array}{c}1.31 * * * \\
(0.29)\end{array}$ & $\begin{array}{c}1.39 * * * \\
(0.34)\end{array}$ \\
\hline Observations & 1,160 & 1,160 & 1,157 & 787 & 787 & 757 \\
\hline $\begin{array}{l}\text { Experience } \\
\text { Other qualifications }\end{array}$ & & yes & $\begin{array}{l}\text { yes } \\
\text { yes }\end{array}$ & & yes & $\begin{array}{l}\text { yes } \\
\text { yes }\end{array}$ \\
\hline
\end{tabular}

Notes: Fixed effects for party group interacted with fixed effects for election periods are included in all specifications. Robust standard errors in parentheses. * significant at 10\%; ** significant at 5\%; *** significant at 1\%. Control variables are listed under Table 1.

A final note on the results in columns $4-6$ of Table 3 is that they strongly legitimize our operationalization of the career ladder for elected politicians. The estimate for holding the midlevel position (L2) on the probability of reaching the top level (L3) is highly significant and has a positive sign. A politician who has advanced to level 2 of the political hierarchy is about 140 percent more likely to be promoted to the top level than a politician who is presently at level 1. 
Criterion 4: Gender and racial inequalities in holding influential positions increase over the course of a political career, and the differentials are greater for more influential positions.

We have panel data for political appointments in two election periods, which makes it empirically challenging to test criterion 4. Following the cross-sectional approach of Cotter et al. (2001) we compare the probabilities that women and minorities hold positions of influence across increasing levels of previous experience. To meet criterion 4 , we expect a growing differential for longer tenures, and a larger increase in that differential for the top position than for the mid-level position.
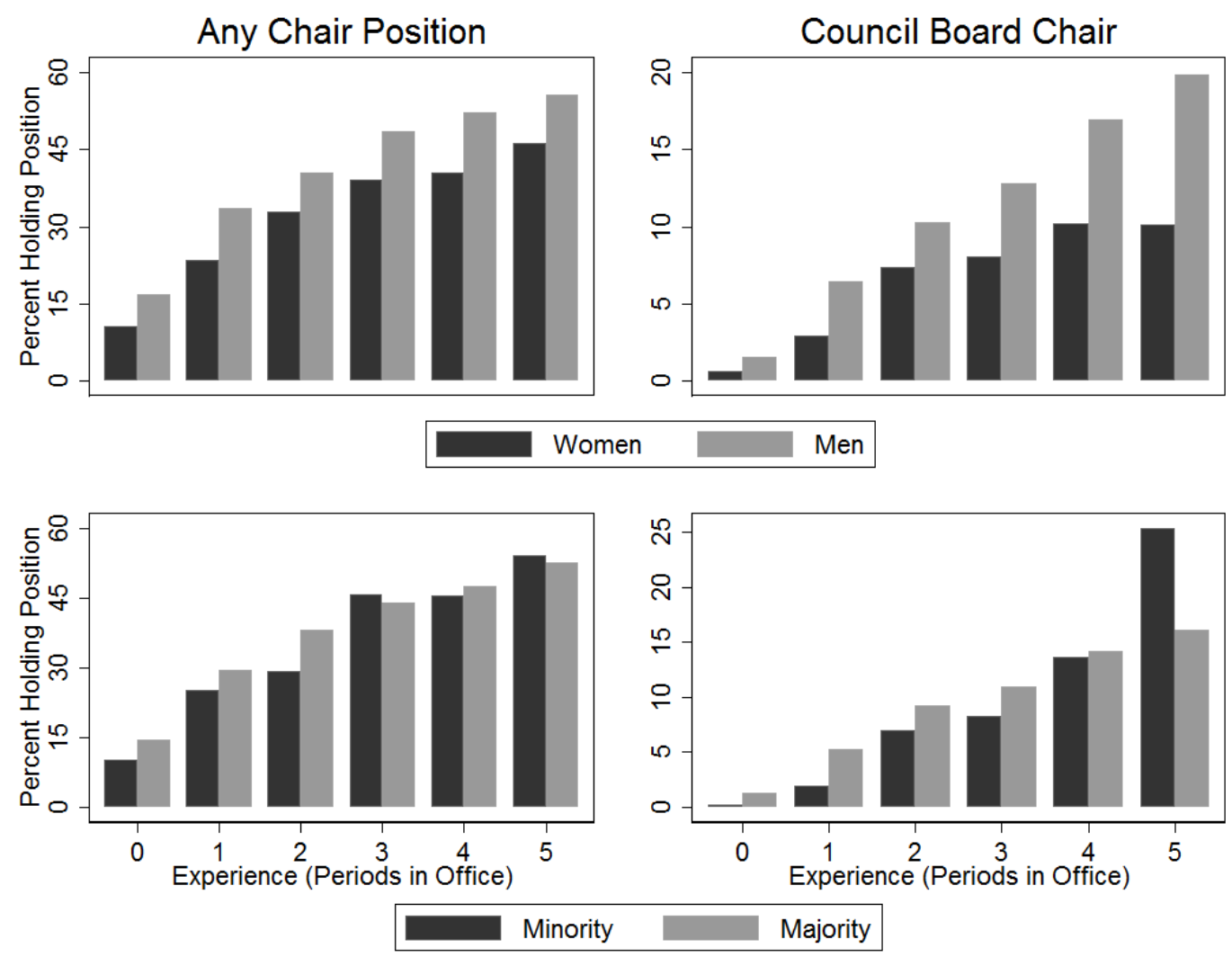

Figure 2. Gender (top) and racial (bottom) inequality in the proportion of individuals that holds influential positions by total tenure in elected office, pooled 2006 and 2010 data. 
Figure 2 shows that total tenure is positively correlated with holding a position of influence for all socioeconomic groups. It also appears that the payoff for experience is greater for men than for women, and that this inequality widens more with the level of experience when we examine the top position. In contrast, minorities have a disadvantage at the lower levels of tenure but not at the higher ones. At first glance, criterion 4 appears to be met in the case of women but not in the case of minorities.

A formal regression analysis is carried out to estimate the differential probabilities in holding influential appointments across the five levels of political tenure while also holding other qualifications constant (a detailed description and numerical estimates are provided in Section S.3). Figure 3 plots the predicted probabilities from this regression analysis and illustrates the statistical precision with a 95 percent confidence interval.

Figure 3 confirms the preliminary conclusions from the descriptive analysis in Figure 2. The gender inequality in the probability of holding positions of influence is constant over the career trajectory for the mid-level position and increasing for the top position (as seen by the divergence of the estimated probabilities for men and women in the top-right graph). That women's disadvantage is statistically significant for each level of experience can be seen by the lack of an overlap between the confidence interval for women's predicted probability and the line showing the male estimates. For minorities, there is a statistically significant disadvantage in obtaining both positions among politicians with the lowest levels of experience. However, no statistically significant gap is observed for politicians with longer tenures. 

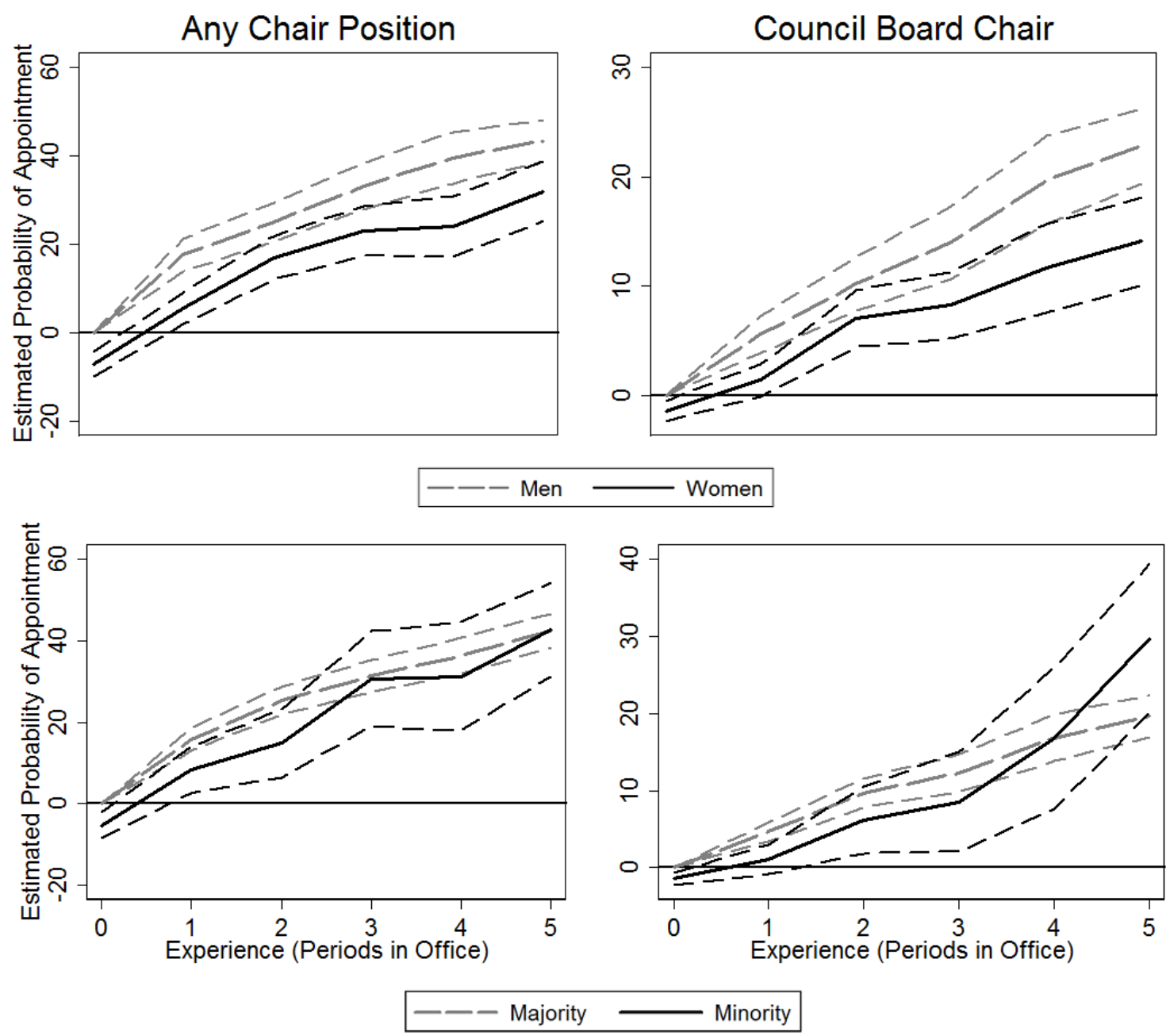

Figure 3. Estimated gender (top) and racial (bottom) inequality in the proportion of individuals that holds influential positions by total tenure in elected office, pooled 2006 and 2010 data.

The results in this section should be interpreted with caution, because our cross-sectional approach may confound career and cohort effects. Because politicians with more experience come from older cohorts, gender and racial inequalities could be more salient. For minorities, cohorts also correlate with unobserved variation across first- and second-generation immigrants. It could also reflect a status hierarchy of regions of origin, with earlier cohorts coming from European countries having higher status and an easier way of entering into 
political organizations, and later cohorts from outside of Europe having lower status and a harder time of doing so.

\section{Alternative Specifications}

We look at two alternative specifications for the empirical analysis. The first addresses the concern that gender differences in the prioritization of family-related caregiving responsibilities drive our baseline findings of a glass ceiling for women. We restrict our sample to politicians who have never had a child between the ages of 0 and 6 during any of their years as elected representatives. The results, shown in section S.4 in the Supporting Information (Tables S.6S.8 and Figures S.3 and S.4), are highly similar to the baseline findings.

The second alternative specification excludes second-generation immigrants from the definition of minority status, only keeping individuals who are born outside of Sweden. Interestingly, this analysis slightly alters the results (Tables S.9-S.11 and Figures S.5 and S.6). In all four empirical tests we find larger estimated inequalities between minority and majority representatives. These results could mirror improved political integration over time of the polyethnic minorities of immigrant origin. But they could also be the consequence of the redirection over time of immigration flows to Sweden from within Europe to outside of Europe as illustrated by Table S.4 in the Supporting Information. Nevertheless, because we still see larger inequalities in the probability of holding, or being promoted to, a mid-level position compared to the top position, we still reject the glass ceiling effect. 


\section{Discussion and Conclusions}

This paper contributes to our understanding of the absence of women and minorities from the top positions of political power. We formalize criteria and suggest an empirical strategy to test one potential explanation of this phenomenon, namely that a glass ceiling hinders women and minorities from climbing to the top of organizational hierarchies. This explanation firmly ties career disadvantages to the promotion process within the political organization. It thus differs from macro-level explanations (features of the electoral and party system, cultural norms, etc.) as well as from other micro-level explanations (a weak supply of experienced and otherwise qualified candidates, or that women prioritize caregiving work in the family over their political career).

Our empirical tests for the Swedish context show that both women and polyethnic minorities face disadvantages in climbing the political career ladder. For women, this pattern fits the metaphor of a glass ceiling. For minorities, the disadvantages correspond more closely to the metaphor of a sticky floor: the obstacles to advancement from the entry level to the midlevel are more severe than those for advancing from the mid-level to the top. These results illustrate the usefulness of our empirical strategy in locating bottlenecks for the career paths of political minorities.

Some efforts to promote vertical equality that stems from a glass ceiling effect will be more productive than others. First and foremost, a "wait and see" approach is not sufficient. Even direct efforts to improve the supply of qualified women and minorities will likely fall short as long as equally qualified women and minorities are denied equal promotion chances. More successful strategies should target the norms, behaviors, and party practices that surround parties' promotion processes. In the Swedish context, such strategies should focus on the recruitment of women for top appointments, and of minorities for mid-level appointments. At 
the same time, our results do not imply that the glass ceiling is the only explanation for vertical inequality in the Swedish context. Previous research has pointed out that a faster exit rate of women from the political arena, controlled for in this paper by the experience variable, is related to family responsibilities and discriminatory behavior by the party organization (Folke and Rickne, 2014).

Fully identifying the channels for discriminatory promotions is outside the scope of this work, but previous work gives ample clues that can be pursued in future work. Notably, discrimination may be largely or entirely unintentional on the part of recruiters and/or party elites. As party recruiters are mostly majority men, similarity of socioeconomic characteristics, attitudes, values, and personality between this in-group (perceiver) and candidates for promotion may be interpreted as qualifications (Bjarnegard 2009; Lipman-Blumen 2000; Piliavin 1987). In turn, social similarities lead to an assumption of competence in a way that favors the dominant group (Holgersson 2003; Klahr 1969; Schlozman, et al. 1995).

Factors outside of the political party may also affect recruiters' impressions of the available candidates. Media bias against female politicians is widely documented, including a focus of political commentary on their physical appearance and private lives, and less on their political positions (e.g., Dolan, Deckman and Swears 2007; Kahn and Goldenberg 1991; Ondercin and Welch 2005). Perceived voter bias against women and minorities as political leaders could also factor into promotion decisions (Norris and Lovenduski 1995).

There are many avenues for future research. In our case study, the conclusion about the glass ceiling for women was sustained in a subsample of politicians without children. In a separate survey dataset, we also showed highly similar levels of desired political tenures (a proxy for ambition) and policy-making efforts across sexes and political positions. Despite these efforts, future work could directly combine promotion data with datasets on work efforts and/or politicians' preferences to more fully control for unobserved characteristics. Ensuring 
that residual disparities in promotion probabilities are solely due to sex or minority status is crucial for drawing correct conclusions regarding the glass ceiling effect. Future work could also use longer time series on promotions, preferably whole political careers, to ensure that tests of promotion disparities over career trajectories are not confounded by cohort effects.

Another obvious area of interest is to replicate our study on data from other countries and political systems. In the US case, comparisons could include movements across hierarchies of appointments both within and across chambers of legislatures, and to top executive positions. Future tests could also extend career paths to stages prior to elected office. The present study suggests that in the Swedish case, the steps of party membership, nomination to the party lists, and climbing to an electable position on that list could be particularly relevant bottlenecks for polyethnic minorities. Finally, the present analysis could be extended to intersectional glass ceilings or to provide further heterogeneity analysis between status hierarchies of different groups of polyethnic minorities. 


\section{References}

Albrecht, James, Anders Bjorklund, and Susan Vroman. 2003. "Is There a Glass Ceiling in Sweden?" Journal of Labor Economics 21 (1): 145-77.

Arulampalam, Wiji, Alison L. Booth, and Mark L. Bryan. 2007. "Is There a Glass Ceiling over Europe? Exploring the Gender Pay Gap across the Wage Distribution." Industrial and Labor Relations Review 60 (2): 163-86.

Bækgaard, Martin, and Ulrik Kjaer. 2012. "The Gendered Division of Labor in Assignments to Political Committees: Discrimination or Self-Selection in Danish Local Politics?" Politics \& Gender 8 (4): 465-82.

Baxter, Janeen, and Erik Olin Wright. 2000a. The Glass Ceiling Hypothesis: A Comparative Study of the United States, Sweden, and Australia. Gender and Society 14 (2): 275-94.

Baxter, Janeen, and Erik Olin Wright. 2000b. The Glass Ceiling Hypothesis: A Reply to Critics. Gender and Society 14 (6): 814-21.

Bjarnegård, Elin. 2009. “Men in Politics. Revisiting Patterns of Gendered Parliamentary Representation in Thailand and Beyond.” Ph.D. Thesis. Uppsala University.

Blondel, Jean. 1987. Political Leadership. London: Sage.

Bloemraad, Irene. 2013. "Accessing the Corridors of Power: Puzzles and Pathways to Understanding Minority Representation." West European Politics 36 (3): 652-70.

Bloemraad, Irene, and Karen Schönwälder. 2013 "Immigrant and Ethnic Minority Representation in Europe: Conceptual Challenges and Theoretical Approaches." West European Politics 36(3): 564-579. 
Carroll, Susan. 1994. Women as Candidates in American Politics (2nd ed.). Bloomington: Indiana University Press.

Carroll, Susan. 2008. “Committee Assignments: Discrimination or Choice?” In Legislative Women: Getting Elected, Getting Ahead, ed. Beth Reingold. Boulder, CO: Lynne Rienner, 135-56.

Carroll, Susan, and Wendy S. Strimling. 1983. Women's Routes to Elective Office: A Comparison with Men. New Brunswick, NJ: Center for the American Women and Politics.

Childs, S. 2004. "A Feminized Style of Politics? Women MPs in the House of Commons." The British Journal of Politics and International Relations 6 (1): 1-22.

Cotter, David A., Joan M. Hermsen, Seth Ovadia, and Reeva Vanneman. 2001. "The Glass Ceiling Effect." Social Forces 80 (2): 655-81.

Cox, Gary W., and Jonathan N. Katz. 1996. "Why Did the Incumbency Advantage in US House Elections Grow?" American Journal of Political Science 40 (2): 478-97.

Dahlstedt, M. 2004. “En av 1.8 miljoner! Röster från ett monokulturellt partiliv” (One of 1.8 million! Voices from mono-cultural party life). In Integrationspolitiska Maktutredningen. Stockholm: Government of Sweden.

Darcy, Robert, Janet Clark, and Susan Welch. 1994. Women, Elections, and Representation. Lincoln and London: University of Nebraska Press. 
Davis, Rebecca Howard. 1997. Women and Power in Parliamentary Democracies: Cabinet Appointments in Western Europe, 1968-1992. Lincoln: University of Nebraska Press.

Dolan, Julie, Melissa M. Deckman, and Michelle L. Swears. 2007. Women and Politics: Path to Power and Political Influence. Upper Saddle River, NJ: Pearson Prentice Hall.

Escobar-Lemmon, M., and M.M. Taylor-Robinson. 2005. "Women Ministers in Latin American Government: When, Where, and Why?" American Journal of Political Science, 49 (4): 829-44.

Esteve-Volart, Berta and Bagues Manuel. 2012. “Are Women Pawns in the Political Game? Evidence from Elections to the Spanish Senate.” Journal of Public Economics 96 (3-4): 387-99.

Fenno, Richard F. 1973. Congressmen in Committees. Boston: Little, Brown.

Federal Glass Ceiling Commission. 1995. Good for Business: Making Full Use of the Nation's Human Capital. U.S. Department of Labor.

Feree, Myra M., and Bandana Purkayastha. 2000. "Equality and Cumulative Disadvantage: Response to Baxter and Wright." Gender \& Society, 14 (6): 809-13.

Ferraz, Claudio, and Frederico Finan. 2011. "Motivating Politicians: The Impacts of Monetary Incentives on Quality and Performance.” Mimeo, Berkeley University.

Folke, Olle and Johanna Rickne. 2014. "Female representation but male rule? Party competition and gender differences in political careers" Mimeo, Columbia University.

Franceschet, Susan, and Jennifer M. Piscopo. 2012. "Gender and Political Backgrounds in Argentina." In The Impact of Gender Quotas, ed. Drude Dahlerup, 43-56. 
Gilljam, Mikael, David Karlsson, and Anders Sundell. 2010. Politik på hemmaplan. Tiotusen fullmäktige-ledamöter tycker om politik och demokrati. Stockholm: SKL Kommentus AB.

Hagevi, Magnus. 2010. “Anciennitetsprincipens uppgång och fall.” In Folkets representanter: En bok om riksdagsledamöter och politisk representation i Sverige, eds. Martin Brotén and Sören Holmberg. University of Gothenburg.

Heath, Michelle, Leslie Schwindt-Bayer, and Michelle Taylor-Robinson. 2005. "Women on the Sidelines: Women's Representation on Committees in Latin American Legislatures.” American Journal of Political Science 49 (2): 420-36.

Herrick, Rebekah. 1995. “A Reappraisal of the Quality of Women Candidates.” Women \& Politics 15 (4): 25-38.

Hirano, Shigeo, and James M. Snyder. 2013. "Primary Elections and the Quality of Elected Officials.” Mimeo, Columbia University.

Holgersson, Charlotte. 2003. Rekrytering av företagsledare: En studie i homosocialitet. Stockholm: Ekonomiska forskningsinstitutet vid Handelshögskolan.

Inglehart, Ronald, and Pippa Norris. 2003. Rising Tide: Gender Equality and Cultural Change around the World. New York: Cambridge University Press.

Jalalzai, Farida. 2013. "Shattered, Cracked, or Firmly Intact? Women and the Executive Glass Ceiling Worldwide.” New York: Oxford University Press.

Jalalzai, Farida, and Krook, Mona Lena. 2010. 'Beyond Hillary and Benazir: Women’s Political Leadership Worldwide.” International Political Science Review 31 (1): 5-23. 
Kahn, Kim F., and Goldenberg, Edie N. 1991. "Women Candidates in the News: An Examination of Gender Differences in U.S. Senate Campaigns.” Public Opinion Quarterly 55 (2): 180-99.

Kee, Hiau, J. 2005. "Glass Ceiling or Sticky Floor? Exploring the Australian Gender Pay Gap using Quantile Regression and Counterfactual Decompositon Methods." Discussion Paper 487, The Australian National University, Centre for Economic Policy Research.

Kenski, Kate, and Erika Falk. 2004. "Of What is that Glass Ceiling Made? A Study of Qttitudes about Women and the Oval Office." Women \& Politics 26 (2): 57-80.

Klahr, David. 1969. "Decision Making in a Complex Environment: The Use of Similarity Judgments to Predict Preferences.” Management Science 15: 593-618.

Kobayashi, Yoshie. 2004. "Has the Closed Door Opened for Women? The Appointment of Women Ministers in Japan." Symposium on Open Boundaries Workshop: Women and Politics in Comparative Perspective, APSAnet January 2004.

Kropf, Martha E., and John A. Boiney. 2001. "The Electoral Glass Ceiling: Gender, Viability, and the News in US Senate Campaigns." Women \& Politics 23 (1-2): 79-103.

Krook, Mona Lena, and Diana Z. O’Brien. 2012. "All the President's Men? The Appointment of Female Cabinet Ministers Worldwide." The Journal of Politics 74 (3): 840-55.

Kymlicka, Will. 1995. Multicultural Citizenship. Oxford: Oxford University Press.

Lépinard, Éléonore. 2013 "For Women Only? Gender Quotas and Intersectionality in France." Politics \& Gender 9 (3): 276-98.

Lipman-Blumen, Jean. 2000. Connective Leadership. New York: Oxford. 
Martin, Lynn. 1991. A Report on the Glass Ceiling Commission. Washington, DC: U.S. Department of Labor.

Matthews, Donald. 1969. U.S. Senators and their World. Chapel Hill: University of North Carolina Press.

Montin, Stig. 2007. Moderna Kommuner. Malmö: Liber.

Morgan, Laurie. A. 1998. "Glass-ceiling Effect or Cohort Effect? A Longitudinal Study of the Gender Earnings Gap for Engineers, 1982 to 1989." American Sociological Review 63:479-93.

Morgenstern, Scott, and Benito Nacif (eds). 2002. Legislative Politics in Latin America. Cambridge: Cambridge University Press.

Norris, Pippa (ed.). 1997. Passages to Power: Legislative Recruitment in Advanced Democracies. Cambridge: Cambridge University Press.

Norris, Pippa, and Joni Lovenduski. 1995. Political Recruitment: Gender, Race and Class in the British Parliament. Cambridge: Cambridge University Press.

Norrander, Barbara, and Clyde Wilcox. 1998. "The Geography of Gender Power: Women in State Legislatures." In Women and Elective Office: 103-17., eds. Sue Thomas and Clyde Wilcox. New York: Oxford University Press.

O’Brien, Diana. 2014. "Rising to the Top: Gender, Political Performance, and Party Leadership in Advanced Industrial Democracies.” Mimeo . University of Southern California 
Ondercin, Heather L., and Susan Welch. 2005. "Women Candidates for Congress.” In Women and Elective Office: Past, Present, and Future (2nd ed.), eds. S. Thomas and C. Wilcox. New York: Oxford University Press, 60-80.

Palmer, Barbara, and Dennis Simon. 2001. "The Political Glass Ceiling: Gender, Strategy, and Incumbency in US House Elections, 1978-1998." Women \& Politics 23 (1-2): 5978.

Palmer, Barbara, and Dennis Simon. 2010. Breaking the Political Glass Ceiling: Women and Congressional Elections. New York: Routledge.

Piliavin, Jane. 1987. “Age, Race, and Sex Similarity to Candidate and Voting Preference.” Journal of Applied Social Psychology 17: 351-68.

Prokos, Anastasia, and Irene Padavic. 2005. "An Examination of Competing Explanations for the Pay Gap among Scientists and Engineers." Gender \& Society 19.4: 523-43.

Reynolds, Andrew. 1999. "Women in the Legislatures and Executives of the World: Knocking at the Highest Glass Ceiling." World Politics 51 (4): 547-72.

Rodriguez, Victoria E. 2003. Women in Contemporary Mexican Politics. Austin: University of Texas Press.

Ryan, Michelle K., and S. Alexander Haslam. 2005. “The Glass Cliff: Evidence that Women are Over-Represented in Precarious Leadership Positions.” British Journal of Management 16 (2): 81-90.

Ryan, Michelle K., and S. Alexander Haslam. 2007 "The glass cliff: Exploring the dynamics surrounding the appointment of women to precarious leadership positions." Academy of Management Review 32(2): 549-572. 
Sanbonmatsu, Kira. 2002. "Political Parties and the Recruitment of Women to State Legislatures." The Journal of Politics 64 (3): 791-809.

Sapiro, Virginia. 1982. "Private Costs of Public Commitments or Public Costs of Private Commitments? Family Roles versus Political Ambition.” American Journal of Political Science 26: 265-79.

Schlozman, Kay L., Nancy, Burns, Sidney Verba, and Jesse Donahue. 1995. "Gender and Citizen Participation: Is There a Different Voice?” American Journal of Political Science,39 (2): 267-93.

Schwindt-Bayer, Leslie A. 2005. “The Incumbency Disadvantage and Women's Election to Legislative Office.” Electoral Studies 24 (2): 227-44.

Schwindt-Bayer, Leslie A. 2011. "Women who Win: Social Backgrounds, Paths to Power, and Political Ambition in Latin American Legislatures." Politics \& Gender 7 (1): 1-33.

Siaroff, Alan. 2000. "Women's Representation in Legislatures and Cabinets in Industrial Democracies." International Political Science Review 21 (2): 197-215.

Soininen, Maritta. 2011. "Ethnic Inclusion or Exclusion in Representation." In The Political Representation of Immigrants and Minorities. Voters, Parties and Parliaments in Liberal Democracies, eds. K. Bird, T. Saalfeld and A. Wüst. Houndmills. Basingstoke: Palgrave.

Soininen, Maritta, and Nils Etzler. 2006. Partierna nominerar: Exkluderingens mekanismeretnicitet och representation [Political Party Candidate Selection: Mechanisms of Exclusion, Ethnicity and Representation]. SOU :53.

Stokes, Wendy. 2005. Women in Contemporary Politics. Cambridge, UK: Polity Press. 
Thomas, Gwynn, and Melinda Adams. 2010. "Breaking the Final Glass Ceiling: The Influence of Gender in the Elections of Ellen Johnson-Sirleaf and Michelle Bachelet." Journal of Women, Politics \& Policy 31 (2): 105-31.

Thomas, Sue. 2002. "The Personal is the Political: Antecedents of Gendered Choices of Elected Representatives.” Sex Roles 47 (7-8): 343-53.

Trimble, Linda, and Jane Arscott. 2003. Still Counting: Women in Politics across Canada. Toronto: University of Toronto Press.

UN Women. 2014. "Progress for Women in Politics, but Glass Ceiling Remains Firm.” Press Release, 11 March 2014, http://www.unwomen.org/en/news/stories/2014/3/progressfor-women-in-politics-but-glass-ceiling-remains-firm\#sthash.7FqvEsLe.dpuf. [Accessed 25 May 2014]

Verge, Tània. 2010. “Gendering Representation in Spain: Opportunities and Limits of Gender Quotas.” Journal of Women Politics and Policy 31 (2): 166-90.

Wide, Jessika, 2011. "Kvinnors vertikala marginalisering i kommunalpolitiken i Sverige." Mimeo, Umeå University.

Yule, Jean. 2000. "Women Councillors and Committee Recruitment." Local Government Studies $26(1): 31-54$. 


\section{Supporting Information}

\section{S.1. Defining the Political Hierarchy in Swedish Municipalities}

Our operationalization of the political hierarchy is supported by previous research on the functions of Swedish municipalities. A 2010 survey that asked municipal politicians to rank political positions in terms of their influence clearly placed the council board chair at the top, followed by the chair of the municipal council, and then by the subcommittee chairs (Gilljam, Karlsson and Sundell 2010). As further explained by Montin (2007), the council board chair is substantially more powerful than the assembly chair, despite the superior formal powers of the latter. ${ }^{8}$ Our suggested hierarchy of positions is also reflected by the monetary compensation of the positions. The positions of entry-level politicians are honorary, with low piece-rate payments for individual meetings. Among mid-level politicians, large municipalities usually grant part-time or even full-time political employment to one or several individuals. Meanwhile, the top position is a full-time political job in all but a handful of the smallest municipalities.

There are, of course, alternative ways in which we could have operationalized the political hierarchy. One alternative would have been to differentiate between subcommittee chairs in terms of funding or coordinating power and/or so-called prestige committees (Carroll 2008). It is commonly known that women are over-represented in committees that deal with "soft" issues such as education, environment, leisure, municipal services, nursery, etc., while men are over-

\footnotetext{
${ }^{8}$ The chair of the council board is the leader of the political work of the largest political party in the governing majority, but he or she also has direct operative employer responsibility for the one-fifth of the Swedish labor force that is employed by the municipalities. In most municipalities, he or she is also the chair of the board of the holding company for the municipal public firms.
} 
represented in "hard" areas such as finance, planning, information technology, passenger transport, and technical services (e.g., Baekgaard and Kjaer 2012; Yule 2000). As pointed out by Baekgaard and Kjaer (2012), this "division of labor" should not be considered discriminatory if it is because men and women have different committee preferences. More importantly, the context of the Swedish municipality lends itself less to the standard ranking of issue importance. Because the areas of elderly and childcare, education, and social issues are key areas in the municipalities' political responsibilities, chairing these committees can hardly be defined as marginalization (Wide 2011). In Table S.1 we show the proportion of female chairs by committee type in our dataset. If we measure committees' political importance by the proportion that has a chair who is a full-time employed politician, or by the number of existing chairs (i.e., the commonality of specific subcommittee types), we do not see any clear evidence that women are marginalized to less politically important positions. ${ }^{9}$

\footnotetext{
${ }^{9}$ A second alternative specification of the political hierarchy could have been to take into account the fact that a person can hold more than one chair position. The data, however, show that only 6 percent of the chairs have double committees, and men are not dramatically over-represented in this category.
} 
Table S.1 Descriptive statistics of subcommittee chairs, pooled data for 2006 and 2010.

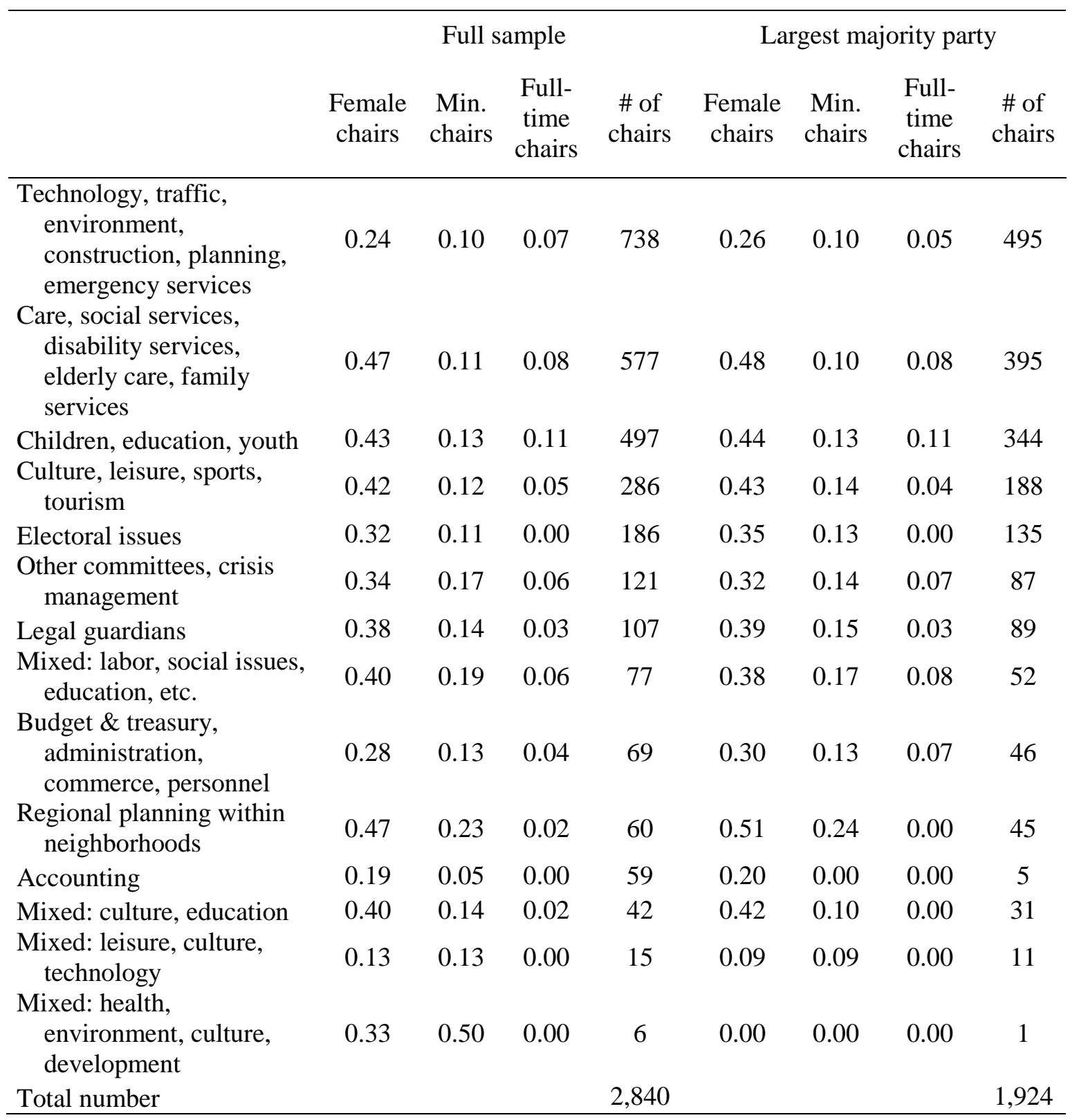

\section{Section S.2 Details on Qualification Measures}

Besides the length of tenure in the municipal assembly, our first measure of qualifications for higher political office is the level of education. This measure has been extensively used in studies of political selection to capture enhanced practical skills, signaling ability, and civic engagement (Baltruite et al. 2012; Besley and Reynal-Querol 2011; De Paola and Scoppa 2011; 
Ferraz and Finan 2011; Franceschet \& Piscopo 2012; Galasso and Nannicini 2011; SchwindtBayer 2011). We divide politicians into seven categories of educational attainment, ranging from having nine years of education to having a doctorate degree, and create one binary indicator for each category. The second measure of qualifications is age (following, e.g., Franceschet and Piscopo 2012), which we capture using categorical dummy variables for five age intervals: $18-29,30-49,50-60,61-64$, and 65 or above. ${ }^{10}$

The third qualification measure is a binary indicator for whether the politician has previous experience as a parliamentarian. The fourth and final measure captures the politician's occupation sector in the non-political labor market. This measure departs from the view that the skill sets developed in different labor market sectors differ in their relevance for the political arena (Messner and Polborn 2004). ${ }^{11}$ We chose to be agnostic on which occupations are more beneficial for the political sector and instead include binary indicators for ten aggregate employment sectors.

We do not include a politician's preferential vote support as a qualification measure. In Sweden, voters can cast one voluntary preferential vote and usually do so for one of the

\footnotetext{
${ }^{10}$ Including a separate indicator for the 61-64 range is motivated by the fact that these individuals reach retirement age during the election period. Second, women could have weaker formal qualifications. Davis (1997) has highlighted that if women enter into politics at a later average age than men, they may not be in the "right" age bracket when they reach the necessary level of experience.

${ }^{11}$ Some jobs are viewed as more relevant for the political profession, such as the so-called pipeline professions from which U.S. politicians often come: lawyers, business executives, professors, and secondary school teachers (Lawless and Fox 2010). Many studies have tended to add public employment to this list (see, e.g., De Paola and Scoppa 2011; Schwindt-Bayer 2011). Others have classified some jobs as "brokerage jobs" or "politicsfacilitating occupations" such as teachers, journalists, government officials, and political researchers, arguing that persons with these occupational backgrounds have a number of subjective personal characteristics that increase the odds of being selected by the party (Norris and Lovenduski 1995).
} 
politicians at the very top of the electoral ballot. As a consequence, these votes usually have very little impact on which politicians are elected, but previous research has shown that they do serve as qualifications for top positions in Swedish municipal party groups (Folke, Persson and Rickne 2014). Nevertheless, the receipt of such votes is likely to be highly endogenous to the glass ceiling effect. Even in countries where electoral lists are ordered alphabetically, the topranked individual has a large advantage in terms of preferential votes (Esteve-Volart and Bagues 2012). Promotions are thus highly likely to cause an increased vote share, which we cannot disentangle in our data. A control variable for preferential votes would also control for the glass ceiling effect that affects public promotion candidates for top positions that are preferred by the party elite, support in preferential vote campaigns, weaker critique against individual politicians from the local party organization, etc. 
Table S.2A Descriptive statistics for subsample of governing parties and the full dataset, pooled data for 2006 and 2010. Division based on gender.

\begin{tabular}{|c|c|c|c|c|c|c|}
\hline \multirow[b]{2}{*}{ Binary indicator } & \multicolumn{3}{|c|}{ Largest governing party } & \multicolumn{3}{|c|}{ Full sample } \\
\hline & Men & Women & P-value & Men & Women & P-value \\
\hline Minority status & 0.13 & 0.16 & 0.00 & 0.12 & 0.16 & 0.00 \\
\hline Previous parliamentarian & 0.01 & 0.01 & 0.98 & 0.01 & 0.01 & 0.91 \\
\hline \multicolumn{7}{|l|}{ Age } \\
\hline $18-29$ & 0.05 & 0.07 & 0.00 & 0.06 & 0.07 & 0.00 \\
\hline $30-49$ & 0.31 & 0.38 & 0.00 & 0.31 & 0.38 & 0.00 \\
\hline $50-60$ & 0.47 & 0.44 & 0.00 & 0.47 & 0.44 & 0.00 \\
\hline $61-64$ & 0.14 & 0.11 & 0.00 & 0.15 & 0.11 & 0.00 \\
\hline $65+$ & 0.16 & 0.12 & 0.00 & 0.16 & 0.11 & 0.00 \\
\hline \multicolumn{7}{|l|}{ Education } \\
\hline Less than 9 years & 0.05 & 0.02 & 0.00 & 0.05 & 0.02 & 0.00 \\
\hline 9 years & 0.06 & 0.05 & 0.00 & 0.07 & 0.05 & 0.01 \\
\hline Secondary (2 years) & 0.23 & 0.24 & 0.01 & 0.26 & 0.28 & 0.02 \\
\hline Secondary (3 years) & 0.18 & 0.14 & 0.00 & 0.17 & 0.15 & 0.00 \\
\hline Tertiary (less than 3 years) & 0.20 & 0.22 & 0.00 & 0.20 & 0.20 & 0.29 \\
\hline Tertiary (at least 3 years) & 0.27 & 0.33 & 0.00 & 0.25 & 0.29 & 0.00 \\
\hline Research degrees & 0.01 & 0.01 & 0.02 & 0.01 & 0.01 & 0.04 \\
\hline \multicolumn{7}{|l|}{ Occupation sector } \\
\hline Agriculture and fisheries & 0.06 & 0.02 & 0.00 & 0.06 & 0.01 & 0.00 \\
\hline $\begin{array}{l}\text { Mining, smelting, heavy } \\
\text { indust. }\end{array}$ & 0.15 & 0.05 & 0.00 & 0.16 & 0.06 & 0.00 \\
\hline Utilities and waste disposal & 0.02 & 0.00 & 0.00 & 0.02 & 0.00 & 0.00 \\
\hline Construction & 0.04 & 0.01 & 0.00 & 0.04 & 0.01 & 0.00 \\
\hline Services and communications & 0.08 & 0.04 & 0.00 & 0.08 & 0.03 & 0.00 \\
\hline Finance & 0.15 & 0.10 & 0.00 & 0.16 & 0.11 & 0.00 \\
\hline Education & 0.12 & 0.21 & 0.00 & 0.10 & 0.19 & 0.00 \\
\hline Health care & 0.10 & 0.27 & 0.00 & 0.09 & 0.28 & 0.00 \\
\hline Services and culture & 0.14 & 0.14 & 0.72 & 0.16 & 0.15 & 0.27 \\
\hline Public sector & 0.12 & 0.13 & 0.17 & 0.12 & 0.13 & 0.60 \\
\hline \multicolumn{7}{|l|}{ Previous experience } \\
\hline 0 periods (freshmen) & 0.35 & 0.41 & 0.00 & 0.35 & 0.41 & 0.00 \\
\hline 1 period & 0.22 & 0.23 & 0.05 & 0.21 & 0.22 & 0.25 \\
\hline 2 periods & 0.15 & 0.14 & 0.20 & 0.15 & 0.13 & 0.09 \\
\hline 3 periods & 0.09 & 0.09 & 0.86 & 0.09 & 0.10 & 0.39 \\
\hline 4 periods & 0.07 & 0.06 & 0.01 & 0.07 & 0.07 & 0.22 \\
\hline $5+$ periods & 0.12 & 0.06 & 0.00 & 0.13 & 0.07 & 0.00 \\
\hline
\end{tabular}


Table S.2B Descriptive statistics for subsample of governing parties and the full dataset, pooled data for 2006 and 2010. Division based on gender.

\begin{tabular}{|c|c|c|c|c|c|c|}
\hline \multirow[b]{2}{*}{ Binary indicator } & \multicolumn{3}{|c|}{ Largest governing party } & \multicolumn{3}{|c|}{ Full sample } \\
\hline & Majority & Minority & P-value & Men & Women & P-value \\
\hline Women & 0.44 & 0.51 & 0.00 & 0.43 & 0.49 & 0.00 \\
\hline Previous parliamentarian & 0.01 & 0.01 & 0.55 & 0.01 & 0.01 & 0.80 \\
\hline \multicolumn{7}{|l|}{ Age } \\
\hline $18-29$ & 0.06 & 0.10 & 0.00 & 0.05 & 0.09 & 0.00 \\
\hline $30-49$ & 0.33 & 0.40 & 0.00 & 0.33 & 0.42 & 0.00 \\
\hline $50-60$ & 0.46 & 0.43 & 0.08 & 0.46 & 0.42 & 0.00 \\
\hline $61-64$ & 0.14 & 0.09 & 0.00 & 0.14 & 0.08 & 0.00 \\
\hline $65+$ & 0.15 & 0.07 & 0.00 & 0.15 & 0.07 & 0.00 \\
\hline \multicolumn{7}{|l|}{ Education } \\
\hline Less than 9 years & 0.04 & 0.02 & 0.00 & 0.04 & 0.02 & 0.00 \\
\hline 9 years & 0.06 & 0.06 & 0.28 & 0.06 & 0.05 & 0.10 \\
\hline Secondary (2 years) & 0.27 & 0.23 & 0.00 & 0.24 & 0.20 & 0.00 \\
\hline Secondary (3 years) & 0.16 & 0.16 & 0.88 & 0.16 & 0.16 & 0.98 \\
\hline Tertiary (less than 3 years) & 0.20 & 0.21 & 0.59 & 0.21 & 0.22 & 0.08 \\
\hline Tertiary (at least 3 years) & 0.26 & 0.32 & 0.00 & 0.29 & 0.33 & 0.00 \\
\hline Research degrees & 0.01 & 0.01 & 0.90 & 0.01 & 0.02 & 0.01 \\
\hline \multicolumn{7}{|l|}{ Occupation sector } \\
\hline Agriculture and fisheries & 0.04 & 0.01 & 0.00 & 0.04 & 0.02 & 0.00 \\
\hline $\begin{array}{l}\text { Mining, smelting, heavy } \\
\text { indust. }\end{array}$ & 0.12 & 0.09 & 0.00 & 0.11 & 0.10 & 0.22 \\
\hline Utilities and waste disposal & 0.01 & 0.01 & 0.29 & 0.01 & 0.01 & 0.08 \\
\hline Construction & 0.03 & 0.02 & 0.04 & 0.03 & 0.02 & 0.00 \\
\hline Services and communications & 0.06 & 0.06 & 0.65 & 0.06 & 0.06 & 0.60 \\
\hline Finance & 0.14 & 0.15 & 0.22 & 0.13 & 0.13 & 0.88 \\
\hline Education & 0.14 & 0.15 & 0.61 & 0.16 & 0.17 & 0.06 \\
\hline Health care & 0.17 & 0.19 & 0.11 & 0.17 & 0.18 & 0.15 \\
\hline Services and culture & 0.15 & 0.15 & 0.50 & 0.14 & 0.15 & 0.12 \\
\hline Public sector & 0.12 & 0.15 & 0.00 & 0.12 & 0.13 & 0.06 \\
\hline \multicolumn{7}{|l|}{ Previous experience } \\
\hline 0 periods (freshmen) & 0.36 & 0.48 & 0.00 & 0.37 & 0.47 & 0.00 \\
\hline 1 period & 0.22 & 0.22 & 0.72 & 0.22 & 0.24 & 0.02 \\
\hline 2 periods & 0.15 & 0.11 & 0.00 & 0.15 & 0.13 & 0.05 \\
\hline 3 periods & 0.10 & 0.07 & 0.00 & 0.10 & 0.07 & 0.00 \\
\hline 4 periods & 0.07 & 0.05 & 0.01 & 0.07 & 0.04 & 0.00 \\
\hline $5+$ periods & 0.11 & 0.07 & 0.00 & 0.10 & 0.05 & 0.00 \\
\hline
\end{tabular}


Figure S.1 Self-declared desired future tenure in the municipal council, 2012.

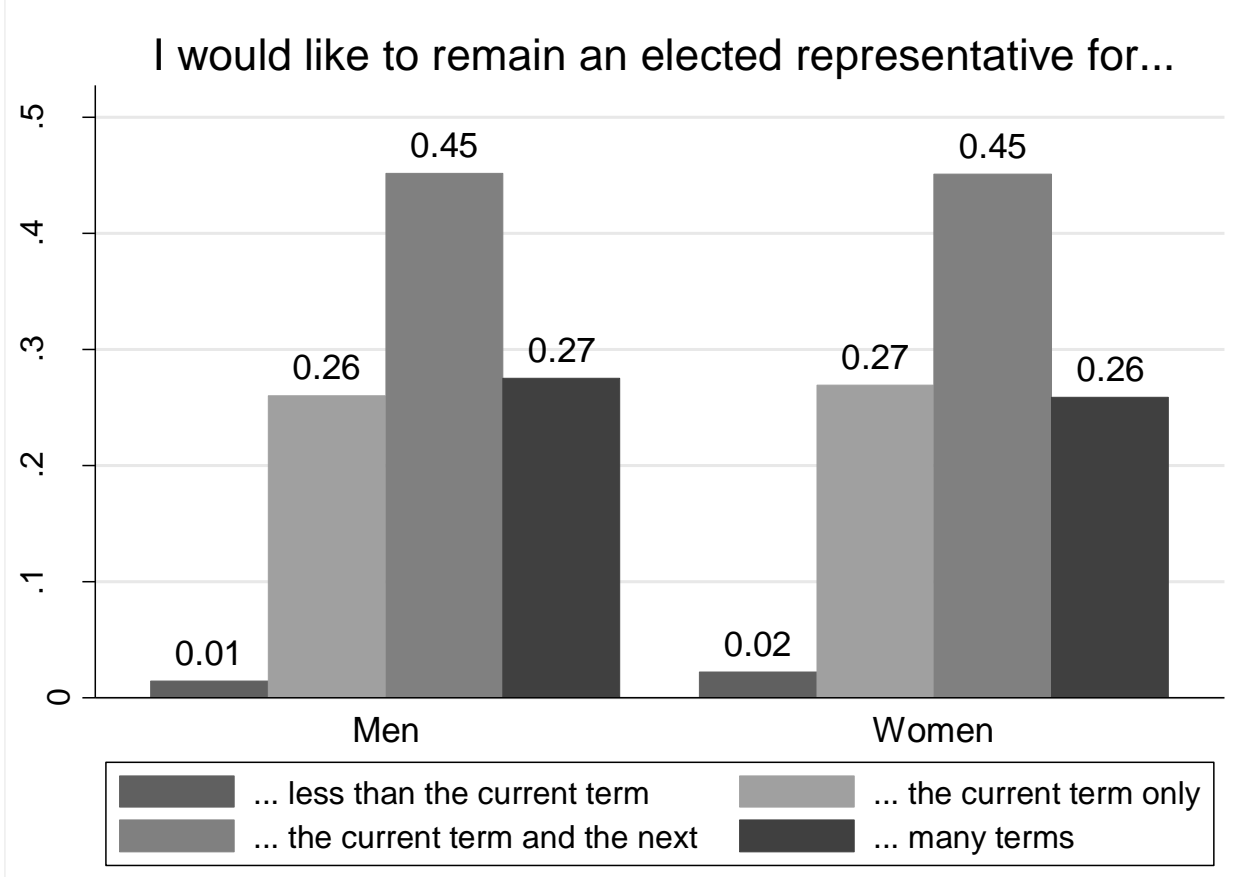

Source: 2012 Survey of Swedish Local Politicians (Gilljam and Karlsson 2009); n = 9,245. 
Figure S.2 Self-declared desired future tenure in the municipal council among politicians born in Sweden vs. outside of Sweden, 2012.

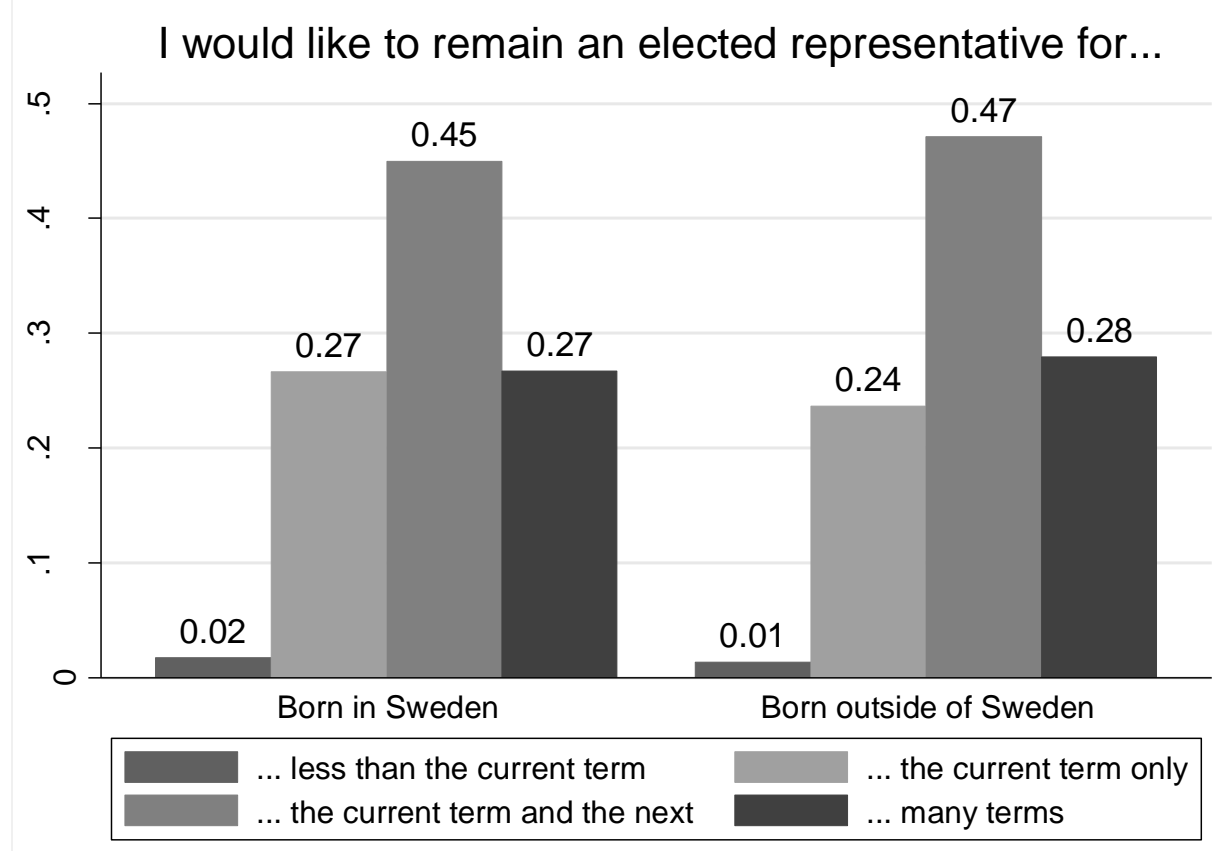

Source: 2012 Survey of Swedish Local Politicians (Gilljam and Karlsson 2009); n = 9,245. 
Table S.3 Political activity across 14 policy areas by gender, minority status, and position.

\begin{tabular}{lccccccccc}
\hline & $\begin{array}{c}\text { Average \# of policy } \\
\text { areas with no activity }\end{array}$ & \multicolumn{2}{c}{$\begin{array}{c}\text { Average \# of policy } \\
\text { areas written bill }\end{array}$} & $\begin{array}{c}\text { Average \# of policy } \\
\text { areas with written bill } \\
\text { that was passed }\end{array}$ \\
& Men & Women & p-value & Men & Women & p-value & Men & Women & p-value \\
\hline L1: Entry level & 4.9 & 4.8 & 0.13 & 1.1 & 1.0 & 0.00 & 1.6 & 1.5 & 0.00 \\
L2: Committee chair & 4.4 & 4.2 & 0.32 & 0.9 & 0.8 & 0.40 & 2.4 & 2.6 & 0.20 \\
L3: Board chair & 3.0 & 3.1 & 0.85 & 1.3 & 1.1 & 0.59 & 5.6 & 5.2 & 0.48 \\
& & & & & & & & & \\
& Maj. & Min. & p-value & Maj. & Min. & p-value & Maj. & Min. & p-value \\
\cline { 2 - 11 } L1: Entry level & 4.9 & 4.6 & 0.02 & 1.1 & 1.3 & 0.04 & 1.5 & 1.6 & 0.17 \\
L2: Committee chair & 4.3 & 4.5 & 0.73 & 0.9 & 1.0 & 0.50 & 2.5 & 2.3 & 0.61 \\
L3: Board chair & 3.0 & 1.4 & 0.19 & 1.3 & 1.2 & 0.95 & 5.5 & 4.4 & 0.50 \\
\hline N & &
\end{tabular}

Notes: Self-reported activity from the 2012 Survey of Swedish Local Politicians (Gilljam and Karlsson 2009).

The survey question is "Have you, at any time as an elected representative, taken legislative initiatives or supported other person's political initiatives in any of the following policy areas? (you may mark several policy areas)". Areas include the economy, health and child care, schools and education, environmental protection/sustainable development, individual citizen's proposals, women's interests, immigrant group's interests, business owner's interests, union/worker interests, LGBTQ interests, senior citizens, youth organizations, unemployment, local action committees. P-values come from computed t-tests with unequal variances. 
Table S.4 Descriptive statistics for country of origin of first-generation immigrants and parents of second-generation immigrants.

\begin{tabular}{|c|c|c|c|c|c|c|}
\hline & \multirow{2}{*}{\multicolumn{2}{|c|}{$\begin{array}{c}1^{\text {st }} \text { generation } \\
\begin{array}{c}\text { Politician's birth } \\
\text { region }\end{array}\end{array}$}} & \multicolumn{4}{|c|}{$2^{\text {nd }}$ generation } \\
\hline & & & \multicolumn{2}{|c|}{$\begin{array}{l}\text { Mother's birth } \\
\text { region }\end{array}$} & \multicolumn{2}{|c|}{$\begin{array}{l}\text { Father's birth } \\
\text { region }\end{array}$} \\
\hline & $\begin{array}{l}\text { \# of } \\
\text { persons }\end{array}$ & $\begin{array}{l}\text { Share } \\
(\%)\end{array}$ & $\begin{array}{c}\text { \# of } \\
\text { persons }\end{array}$ & $\begin{array}{c}\text { Share } \\
(\%)\end{array}$ & $\begin{array}{c}\text { \# of } \\
\text { persons }\end{array}$ & $\begin{array}{c}\text { Share } \\
(\%)\end{array}$ \\
\hline Other Nordic countries & 214 & 34.9 & 299 & 46.7 & 178 & 21.9 \\
\hline EU27 excluding Nordic countries & 105 & 17.1 & 83 & 13.0 & 110 & 13,51 \\
\hline Asia & 111 & 18.1 & 13 & 2.0 & 9 & 1.1 \\
\hline $\begin{array}{l}\text { Europe excluding Nordic } \\
\text { countries and EU } 27\end{array}$ & 111 & 18.1 & 21 & 3.3 & 21 & 3.3 \\
\hline South America & 36 & 5.9 & 0 & 0 & 2 & 0.2 \\
\hline Africa & 23 & 3.7 & 3 & 0.5 & 4 & 0.5 \\
\hline North America & 10 & 1.6 & 9 & 1.4 & 8 & 1.0 \\
\hline Soviet Union & 1 & 0.2 & 7 & 1.1 & 8 & 1.0 \\
\hline Oceania & 2 & 0.3 & 0 & 0 & 0 & 0 \\
\hline Unknown & 0 & 0 & 206 & 32.1 & 470 & 57.7 \\
\hline Total & 613 & & 641 & 100 & 814 & $100 \%$ \\
\hline
\end{tabular}




\section{Section S.3 Formal Test of Criterion 4}

We extend Equation (1) with a set of interaction terms. This analysis is run for inequalities based on gender and minority status. For each analysis, the binary indicators of either gender or minority status are interacted with each of the binary indicators for the number of terms of previous experience as an elected politician. For gender, this gives the equation:

$Y_{i t}=a_{i t}+\beta_{1} w_{i}+\beta_{E} E_{i t}+\beta_{E W} w_{i} * E_{i t}+\beta Q_{i t}+\gamma_{m t}+\varepsilon_{i t}$.

This specification sets a man with no previous political experience as the reference group for inequalities in the probabilities of holding influential positions over the course of a political career, i.e. when accumulating more periods in elected office. The estimate for the female binary indicator, $\beta_{1}$, provides the difference in the probability of holding an appointment between the average man and woman with zero periods of previous experience. The estimates for 'the returns of experience' (i.e., the received benefit of various levels of experience), $\beta_{E}$, shows the difference between a man with no previous experience and a man with $E_{i t}$ periods of previous experience. Finally, the estimates for the interaction term, $\beta_{E W}$, show the difference in increases in the inequality in the probability of holding an appointment for higher levels of experience. We show the results from this specification, both with and without the controls for qualifications, in Tables S.5A and S.5B below. 
Table S.5A Gender and racial inequalities in the rewards for political experience, 1-5 periods in elected office.

\begin{tabular}{|c|c|c|c|c|}
\hline & \multicolumn{2}{|c|}{$\begin{array}{c}\text { Any chair position }(\mathrm{L} 2+\mathrm{L} 3)=1, \\
\text { otherwise } 0\end{array}$} & \multicolumn{2}{|c|}{$\begin{array}{c}\text { Council board chair }(\mathrm{L} 3)=1, \\
\text { otherwise } 0\end{array}$} \\
\hline & 1 & 2 & 3 & 4 \\
\hline Women & $\begin{array}{c}-5.61 * * * \\
(1.27)\end{array}$ & $\begin{array}{c}-7.11 * * * \\
(1.38)\end{array}$ & $\begin{array}{l}-0.38 \\
(0.39)\end{array}$ & $\begin{array}{c}-1.43 * * * \\
(0.47)\end{array}$ \\
\hline 1 Period & $\begin{array}{c}18.82 * * * \\
(1.90)\end{array}$ & $\begin{array}{l}17.66 * * * \\
(1.90)\end{array}$ & $\begin{array}{l}5.45^{* * *} \\
(0.88)\end{array}$ & $\begin{array}{c}5.57 * * * \\
(0.87)\end{array}$ \\
\hline 2 Periods & $\begin{array}{l}25.81 * * * \\
(2.17)\end{array}$ & $\begin{array}{l}25.03 * * * \\
(2.26)\end{array}$ & $\begin{array}{c}9.50 * * * \\
(1.24)\end{array}$ & $\begin{array}{c}10.21 * * * \\
(1.26)\end{array}$ \\
\hline 3 Periods & $\begin{array}{l}33.60 * * * \\
(2.62)\end{array}$ & $\begin{array}{l}33.19 * * * \\
(2.65)\end{array}$ & $\begin{array}{l}12.44 * * * \\
(1.70)\end{array}$ & $\begin{array}{l}13.99 * * * \\
(1.69)\end{array}$ \\
\hline 4 Periods & $\begin{array}{l}38.28 * * * \\
(2.95)\end{array}$ & $\begin{array}{l}39.68 * * * \\
(2.98)\end{array}$ & $\begin{array}{l}16.89 * * * \\
(2.08)\end{array}$ & $\begin{array}{l}19.70 * * * \\
(2.06)\end{array}$ \\
\hline 5 Periods & $\begin{array}{c}42.15^{* * *} \\
(2.34)\end{array}$ & $\begin{array}{c}43.48 * * * \\
(2.39)\end{array}$ & $\begin{array}{c}19.95 * * * \\
(1.77)\end{array}$ & $\begin{array}{c}22.82 * * * \\
(1.75)\end{array}$ \\
\hline Woman * 1 Period & $\begin{array}{c}-5.08 * * \\
(2.52)\end{array}$ & $\begin{array}{c}-5.00 * * \\
(2.53)\end{array}$ & $\begin{array}{c}-3.04 * * * \\
(1.10)\end{array}$ & $\begin{array}{c}-2.77 * * \\
(1.10)\end{array}$ \\
\hline Woman $* 2$ Periods & $\begin{array}{l}-1.17 \\
(3.15)\end{array}$ & $\begin{array}{l}-0.95 \\
(3.19)\end{array}$ & $\begin{array}{l}-2.00 \\
(1.78)\end{array}$ & $\begin{array}{l}-1.77 \\
(1.78)\end{array}$ \\
\hline Woman * 3 Periods & $\begin{array}{l}-3.17 \\
(3.79)\end{array}$ & $\begin{array}{l}-3.04 \\
(3.75)\end{array}$ & $\begin{array}{l}-4.12^{*} \\
(2.29)\end{array}$ & $\begin{array}{l}-4.30^{*} \\
(2.26)\end{array}$ \\
\hline Woman $* 4$ Periods & $\begin{array}{l}-6.73 \\
(4.67)\end{array}$ & $\begin{array}{l}-8.48 * \\
(4.68)\end{array}$ & $\begin{array}{l}-6.35^{* *} \\
(2.98)\end{array}$ & $\begin{array}{c}-6.65^{* *} \\
(2.95)\end{array}$ \\
\hline Woman $* 5$ Periods & $\begin{array}{l}-5.13 \\
(4.01)\end{array}$ & $\begin{array}{l}-4.33 \\
(3.99)\end{array}$ & $\begin{array}{c}-9.07 * * * \\
(2.82)\end{array}$ & $\begin{array}{c}-7.30 * * * \\
(2.73)\end{array}$ \\
\hline Observations & 8,883 & 8,823 & 8,844 & 8,784 \\
\hline Other qualifications & & yes & & yes \\
\hline
\end{tabular}

Notes: Fixed effects for party group interacted with fixed effects for election periods are included in all specifications. Robust standard errors in parentheses. * significant at 10\%; ** significant at 5\%; *** significant at $1 \%$. Control variables are listed under Table 1. 
Table S.5B Gender and racial inequalities in the rewards for political experience, 1-5 periods in elected office.

\begin{tabular}{|c|c|c|c|c|}
\hline & \multicolumn{2}{|c|}{$\begin{array}{c}\text { Any chair position }(\mathrm{L} 2+\mathrm{L} 3)=1, \\
\text { otherwise } 0\end{array}$} & \multicolumn{2}{|c|}{$\begin{array}{c}\text { Council board chair }(\mathrm{L} 3)=1 \text {, } \\
\text { otherwise } 0\end{array}$} \\
\hline & 1 & 2 & 3 & 4 \\
\hline Minority & $\begin{array}{c}-4.90 * * * \\
(1.58)\end{array}$ & $\begin{array}{c}-5.43 * * * \\
(1.63)\end{array}$ & $\begin{array}{l}-0.41 \\
(0.35)\end{array}$ & $\begin{array}{c}-1.48 * * * \\
(0.39)\end{array}$ \\
\hline 1 Period & $\begin{array}{l}16.77 * * * \\
(1.43)\end{array}$ & $\begin{array}{c}15.82 * * * \\
(1.45)\end{array}$ & $\begin{array}{c}4.41 * * * \\
(0.64)\end{array}$ & $\begin{array}{c}4.63 * * * \\
(0.63)\end{array}$ \\
\hline 2 Periods & $\begin{array}{l}25.83 * * * \\
(1.70)\end{array}$ & $\begin{array}{l}25.33 * * * \\
(1.77)\end{array}$ & $\begin{array}{c}8.81 * * * \\
(0.95)\end{array}$ & $\begin{array}{l}9.70 * * * \\
(0.97)\end{array}$ \\
\hline 3 Periods & $\begin{array}{l}31.36 * * * \\
(1.94)\end{array}$ & $\begin{array}{l}31.33 * * * \\
(1.99)\end{array}$ & $\begin{array}{c}10.66^{* * * *} \\
(1.22)\end{array}$ & $\begin{array}{l}12.27 * * * \\
(1.23)\end{array}$ \\
\hline 4 Periods & $\begin{array}{l}35.28 * * * \\
(2.24)\end{array}$ & $\begin{array}{l}36.34 * * * \\
(2.27)\end{array}$ & $\begin{array}{l}14.13 * * * \\
(1.55)\end{array}$ & $\begin{array}{l}16.84 * * * \\
(1.55)\end{array}$ \\
\hline 5 Periods & $\begin{array}{c}40.86 * * * \\
(2.12)\end{array}$ & $\begin{array}{c}42.53 * * * \\
(2.13)\end{array}$ & $\begin{array}{c}16.28 * * * \\
(1.37)\end{array}$ & $\begin{array}{c}19.66 * * * \\
(1.38)\end{array}$ \\
\hline Minority * 1 Period & $\begin{array}{l}-1.19 \\
(3.36)\end{array}$ & $\begin{array}{l}-2.07 \\
(3.42)\end{array}$ & $\begin{array}{c}-2.32 * * \\
(1.16)\end{array}$ & $\begin{array}{l}-2.09 * \\
(1.19)\end{array}$ \\
\hline Minority $* 2$ Periods & $\begin{array}{l}-3.61 \\
(4.71)\end{array}$ & $\begin{array}{l}-5.09 \\
(4.66)\end{array}$ & $\begin{array}{l}-1.24 \\
(2.59)\end{array}$ & $\begin{array}{l}-2.03 \\
(2.41)\end{array}$ \\
\hline Minority * 3 Periods & $\begin{array}{c}6.50 \\
(5.96)\end{array}$ & $\begin{array}{l}4.78 \\
(6.06)\end{array}$ & $\begin{array}{l}-1.22 \\
(3.44)\end{array}$ & $\begin{array}{l}-2.24 \\
(3.52)\end{array}$ \\
\hline Minority $* 4$ Periods & $\begin{array}{c}2.50 \\
(6.90)\end{array}$ & $\begin{array}{c}0.39 \\
(6.97)\end{array}$ & $\begin{array}{c}0.96 \\
(4.99)\end{array}$ & $\begin{array}{c}1.48 \\
(4.99)\end{array}$ \\
\hline Minority * 5 Periods & $\begin{array}{c}5.67 \\
(6.68)\end{array}$ & $\begin{array}{c}5.70 \\
(6.42)\end{array}$ & $\begin{array}{c}10.78 * * \\
(5.37)\end{array}$ & $\begin{array}{c}11.61 * * \\
(5.11)\end{array}$ \\
\hline Observations & 8,883 & 8,823 & 8,844 & 8,784 \\
\hline Other qualifications & & yes & & Yes \\
\hline
\end{tabular}

Notes: Fixed effects for party group interacted with fixed effects for election periods are included in all specifications. Robust standard errors in parentheses. * significant at 10\%; ** significant at 5\%; *** significant at $1 \%$. Control variables are listed under Table 1.

The results show large returns for experience in the probability of having reached at least a midlevel chair position or the top chair position. The results in Table S.5A suggest that the return of experience is lower for women in terms of getting at least a mid-level chair position. 
However, the point estimates are typically not significant, nor are they clearly increasing with the level of experience. This suggests that there is not a clear career divergence for the probability of getting a mid-level position. For the council board chairs, the inequalities in the returns of experience are both statistically significant and growing with the level of political experience.

For minorities, the estimates in Table S.5B show that none of the interaction effects is statistically significant for the mid-level chair position, and only negatively significant for those with one period of experience. The interaction effect for those with five periods is also positive statistically significant (the combination of the minority dummy and the interaction term is, however, not significant). Thus, the regression results confirm that there are no diverging career trajectories for minority and majority representatives that fit the criterion for a glass ceiling.

Figure 3 in the paper's main text is constructed as follows. For men, we plot the returns of experience, $\beta_{E}$, for each level of experience and their corresponding 95 percent confidence intervals. For women, the payoff of each level of experience is the linear combination of the returns of experience, $\beta_{E}$, the interaction term, $\beta_{E W}$, and the estimate for the female dummy, $\beta_{1}$. The confidence interval for this linear combination is computed in Stata using the "lincom" command. 


\section{Section S.4 Alternative Specifications}

Table S.6 Gender inequality in holding any chair position, or holding the council board chair position, for given levels of qualifications. Excluding all politicians who had at least one small child (0-6 years old) while elected.

\begin{tabular}{|c|c|c|c|c|c|c|}
\hline & \multicolumn{3}{|c|}{$\begin{array}{l}\text { Any chair position }(\mathrm{L} 2+\mathrm{L} 3)=1 \text {, } \\
\text { otherwise } 0\end{array}$} & \multicolumn{3}{|c|}{$\begin{array}{c}\text { Council board chair }(\mathrm{L} 3)=1, \\
\text { otherwise } 0\end{array}$} \\
\hline & 1 & 2 & 3 & 4 & 5 & 6 \\
\hline \multicolumn{7}{|l|}{ Pane A: OLS } \\
\hline Woman & $\begin{array}{l}-10.45^{* * * *} \\
(1.18)\end{array}$ & $\begin{array}{l}-10.45^{* * * *} \\
(1.18)\end{array}$ & $\begin{array}{l}-9.90 * * * \\
(1.21)\end{array}$ & $\begin{array}{c}-3.49 * * * \\
(0.53)\end{array}$ & $\begin{array}{c}-2.80 * * * \\
(0.53)\end{array}$ & $\begin{array}{c}-3.27 * * * \\
(0.61)\end{array}$ \\
\hline \multirow[t]{3}{*}{ Minority } & $-7.61 * * *$ & $-7.61 * * *$ & $-4.90 * * *$ & -0.70 & 0.56 & -0.44 \\
\hline & (1.58) & $(1.58)$ & $(1.49)$ & $(0.79)$ & $(0.78)$ & $(0.77)$ \\
\hline & $(0.56)$ & $(0.56)$ & $(4.60)$ & $(0.25)$ & $(0.37)$ & (1.94) \\
\hline \multicolumn{7}{|l|}{ Observations } \\
\hline & 6,915 & 6,915 & 6,868 & 6,883 & 6,883 & 6,836 \\
\hline \multicolumn{7}{|l|}{ Pane B: Logit } \\
\hline Woman & $\begin{array}{l}-0.52 * * * \\
(0.06)\end{array}$ & $\begin{array}{l}-0.47 * * * \\
(0.06)\end{array}$ & $\begin{array}{c}-0.58 * * * \\
(0.07)\end{array}$ & $\begin{array}{c}-0.78 * * * \\
(0.13)\end{array}$ & $\begin{array}{l}-0.66 * * * \\
(0.13)\end{array}$ & $\begin{array}{l}-0.76 * * * \\
(0.15)\end{array}$ \\
\hline Minority & $\begin{array}{l}-0.41 * * * \\
(0.09)\end{array}$ & $\begin{array}{c}-0.22 * * \\
(0.09)\end{array}$ & $\begin{array}{l}-0.29 * * * \\
(0.09)\end{array}$ & $\begin{array}{l}-0.19 \\
(0.20)\end{array}$ & $\begin{array}{c}0.08 \\
(0.21)\end{array}$ & $\begin{array}{l}-0.07 \\
(0.19)\end{array}$ \\
\hline Observations & 6,766 & 6,766 & 6,713 & 4,206 & 4,206 & 4,140 \\
\hline \multirow{2}{*}{$\begin{array}{l}\text { Experience } \\
\text { Other qualifications }\end{array}$} & & yes & yes & & yes & yes \\
\hline & & & yes & & & yes \\
\hline \multicolumn{7}{|c|}{ Notes: Fixed effects for municipalities interacted with fixed effects for election periods are included in all } \\
\hline \multicolumn{7}{|c|}{ specifications. Robust standard errors in parentheses. * significant at 10\%; ** significant at 5\%; $* * *$ significant } \\
\hline \multicolumn{7}{|c|}{ at $1 \%$. Experience control variables are five binary indicators for $1-5$ periods of previous experience. Other } \\
\hline
\end{tabular}


Table S.7 Gender inequality in holding any chair position vs. being elected, and gender inequality in holding the council board chair position vs. any chair position.

\begin{tabular}{|c|c|c|c|c|c|c|}
\hline & \multicolumn{3}{|c|}{$\begin{array}{l}\text { Mid-level chair position }=1 \\
\quad \text { elected politicians }=0\end{array}$} & \multicolumn{3}{|c|}{$\begin{array}{l}\text { Top-level chair position }=1 \\
\text { mid-level chair position }=0\end{array}$} \\
\hline & 1 & 2 & 3 & 4 & 5 & 6 \\
\hline \multicolumn{7}{|l|}{ Pane A: OLS } \\
\hline Woman & $\begin{array}{c}-8.34 * * * \\
(1.18)\end{array}$ & $\begin{array}{c}-7.07 * * * \\
(1.12)\end{array}$ & $\begin{array}{c}-8.49 * * * \\
(1.22)\end{array}$ & $\begin{array}{c}-6.70 * * * \\
(2.49)\end{array}$ & $\begin{array}{l}-6.33^{* *} \\
(2.50)\end{array}$ & $\begin{array}{l}-7.59 * * * \\
(2.68)\end{array}$ \\
\hline Minority & $\begin{array}{c}-7.20 * * * \\
(1.51)\end{array}$ & $\begin{array}{c}-3.83 * * * \\
(1.43)\end{array}$ & $\begin{array}{c}-4.39 * * * \\
(1.47)\end{array}$ & $\begin{array}{c}2.73 \\
(3.95)\end{array}$ & $\begin{array}{c}4.10 \\
(3.82)\end{array}$ & $\begin{array}{c}2.83 \\
(3.63)\end{array}$ \\
\hline Observations & 6,539 & 6,539 & 6,497 & 1,921 & 1,921 & 1,906 \\
\hline \multicolumn{7}{|l|}{ Pane B: Logit } \\
\hline Woman & $\begin{array}{c}-0.46 * * * \\
(0.06)\end{array}$ & $\begin{array}{c}-0.43 * * * \\
(0.06)\end{array}$ & $\begin{array}{c}-0.53 * * * \\
(0.07)\end{array}$ & $\begin{array}{c}-0.44 * * * \\
(0.15)\end{array}$ & $\begin{array}{c}-0.44 * * * \\
(0.16)\end{array}$ & $\begin{array}{c}-0.59 * * * \\
(0.18)\end{array}$ \\
\hline Minority & $\begin{array}{c}-0.43 * * * \\
(0.09)\end{array}$ & $\begin{array}{c}-0.24 * * * \\
(0.09)\end{array}$ & $\begin{array}{c}-0.27 * * * \\
(0.10)\end{array}$ & $\begin{array}{c}0.18 \\
(0.21)\end{array}$ & $\begin{array}{c}0.27 \\
(0.21)\end{array}$ & $\begin{array}{c}0.20 \\
(0.24)\end{array}$ \\
\hline Observations & 6,200 & 6,200 & 6,158 & 1,262 & 1,262 & 1,241 \\
\hline $\begin{array}{l}\text { Experience } \\
\text { Other qualifications }\end{array}$ & & yes & $\begin{array}{l}\text { yes } \\
\text { yes }\end{array}$ & & yes & $\begin{array}{l}\text { yes } \\
\text { yes }\end{array}$ \\
\hline
\end{tabular}

Notes: Fixed effects for party group interacted with fixed effects for election periods are included in all

specifications. Robust standard errors in parentheses. * significant at 10\%; ** significant at 5\%; *** significant at $1 \%$. Control variables are listed under Table 1. 
Table S.8 Gender inequality in transitions to positions of influence between 2006 and 2010.

Excluding all politicians who had small children while elected.

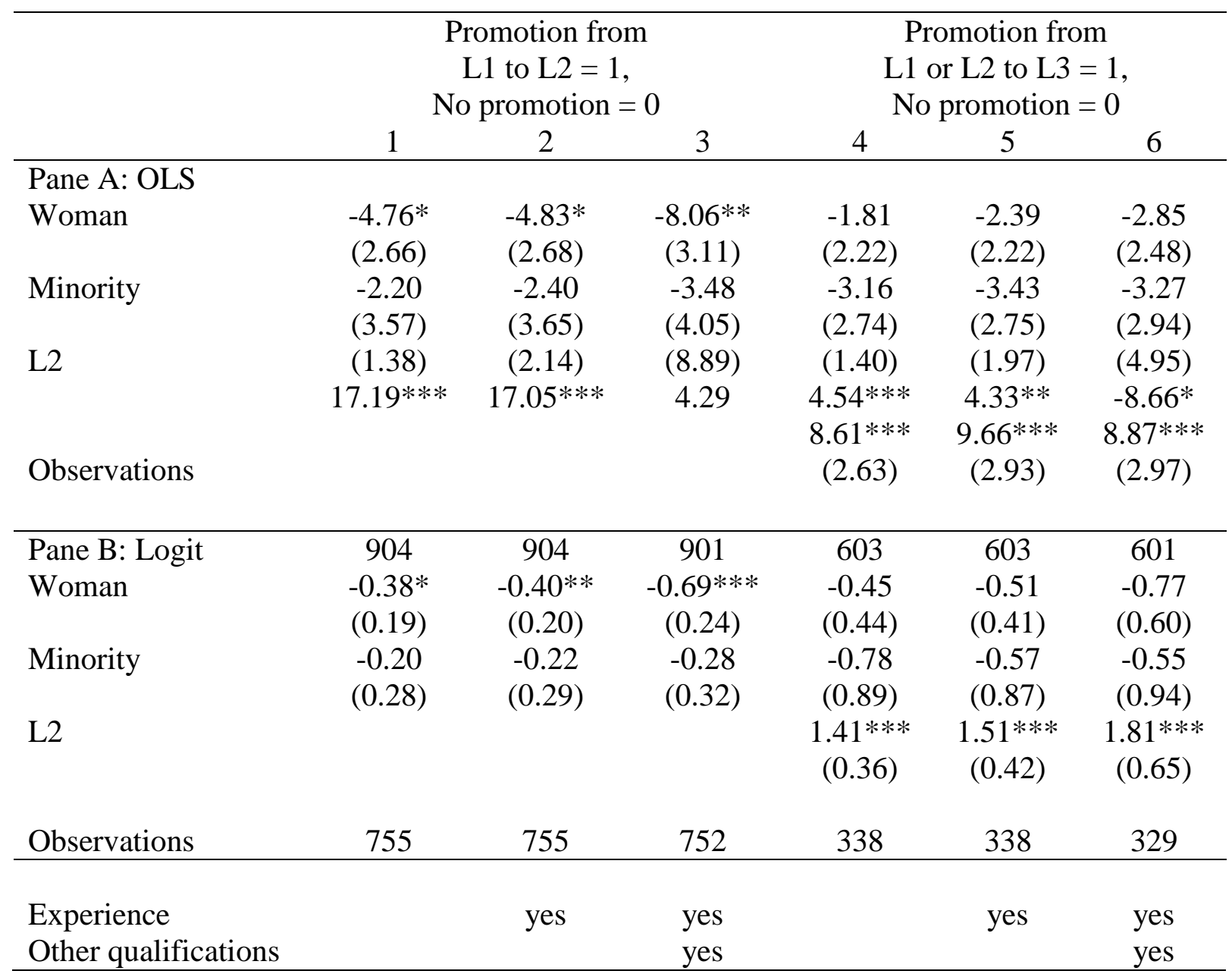

Notes: Fixed effects for party group interacted with fixed effects for election periods are included in all specifications. Robust standard errors in parentheses. * significant at 10\%; ** significant at 5\%; *** significant at 1\%. Control variables are listed under Table 1. 

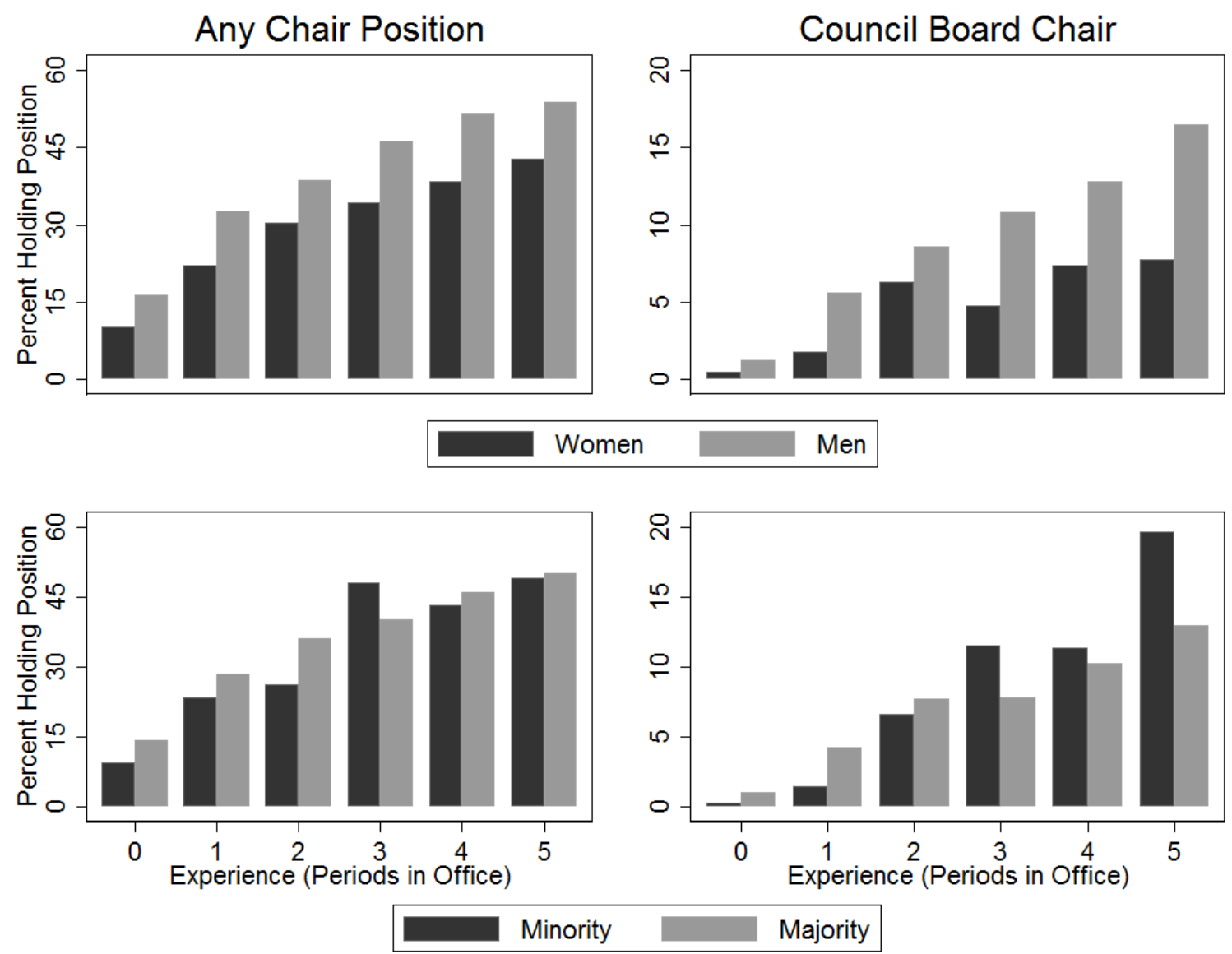

Figure S.3 Gender (top) and racial (bottom) inequality in the proportion of individuals that holds influential positions by total tenure in elected office, pooled 2006 and 2010 data. Excluding all politicians who had small children while elected. 

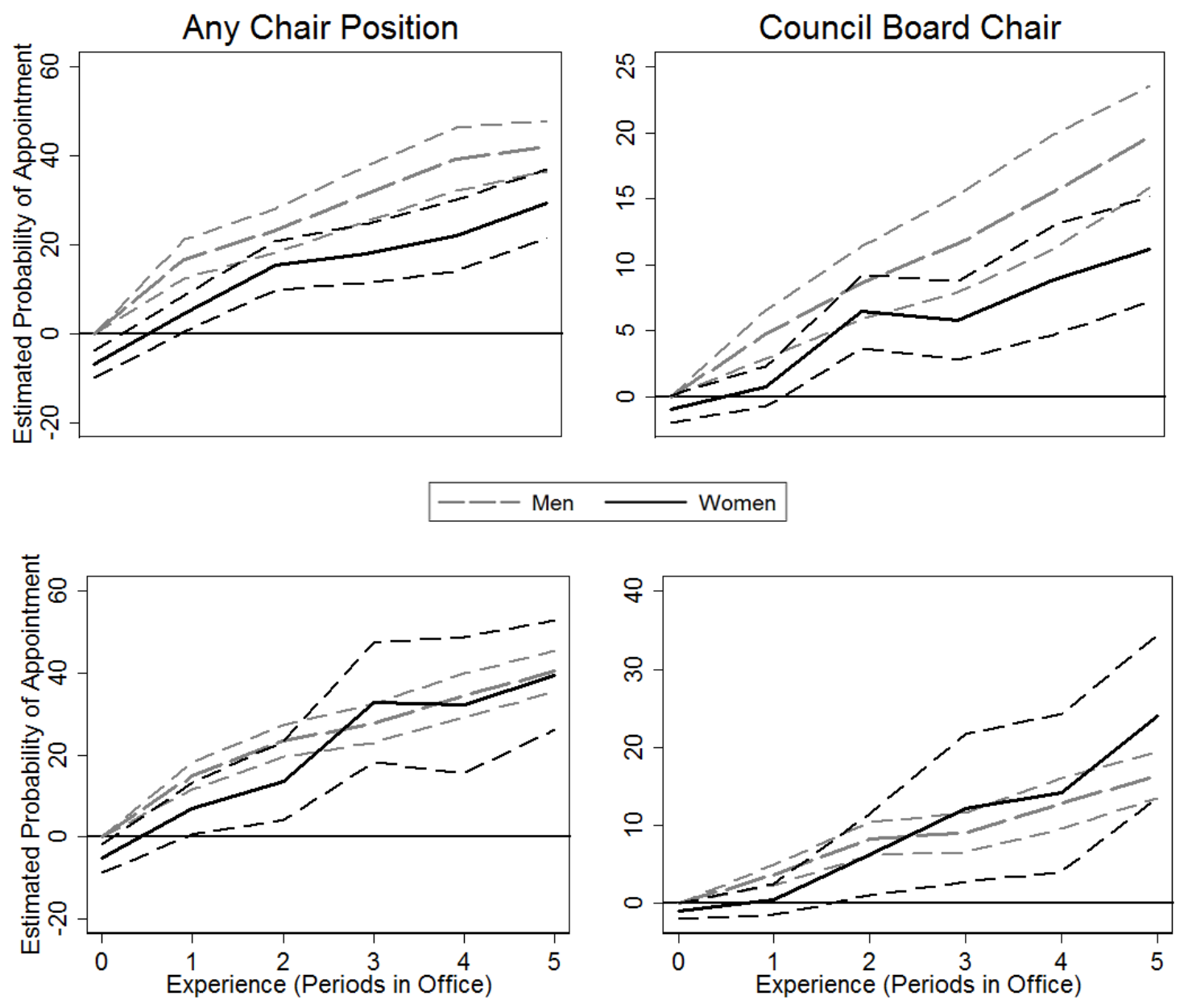

- - Majority Minority

Figure S.4 Estimated gender (top) and racial (bottom) inequality in the proportion of individuals that holds influential positions by total tenure in elected office, pooled 2006 and 2010 data. Excluding all politicians who had small children while elected. 
Table S.9 Inequality in holding any chair position, or holding the council board chair position, for given levels of qualifications. Only first-generation immigrants included in minority definition.

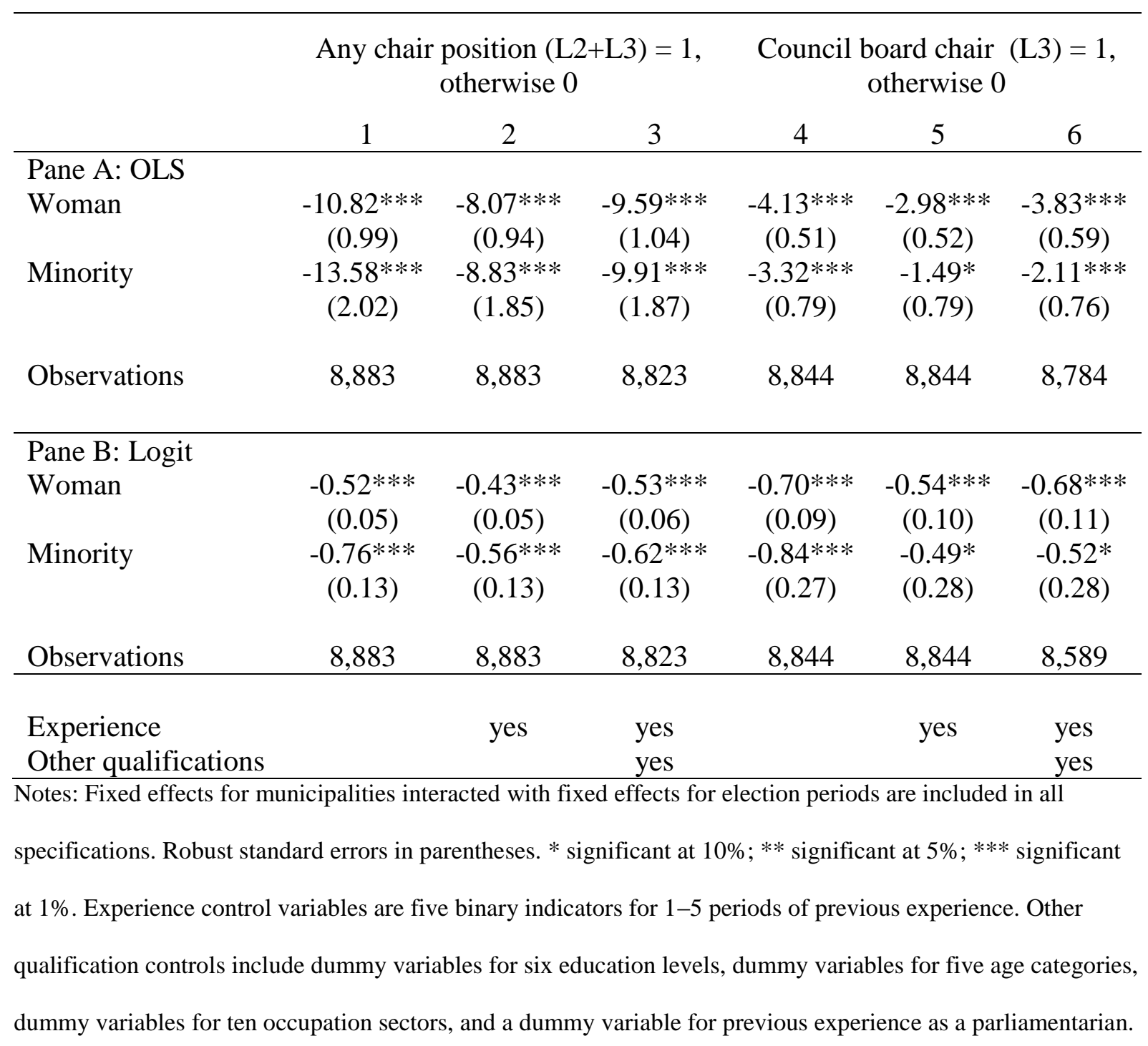


Table S.10 Inequality in holding any chair position vs. being elected, and inequality in holding the council board chair position vs. any chair position. Only first-generation immigrants included in minority definition.

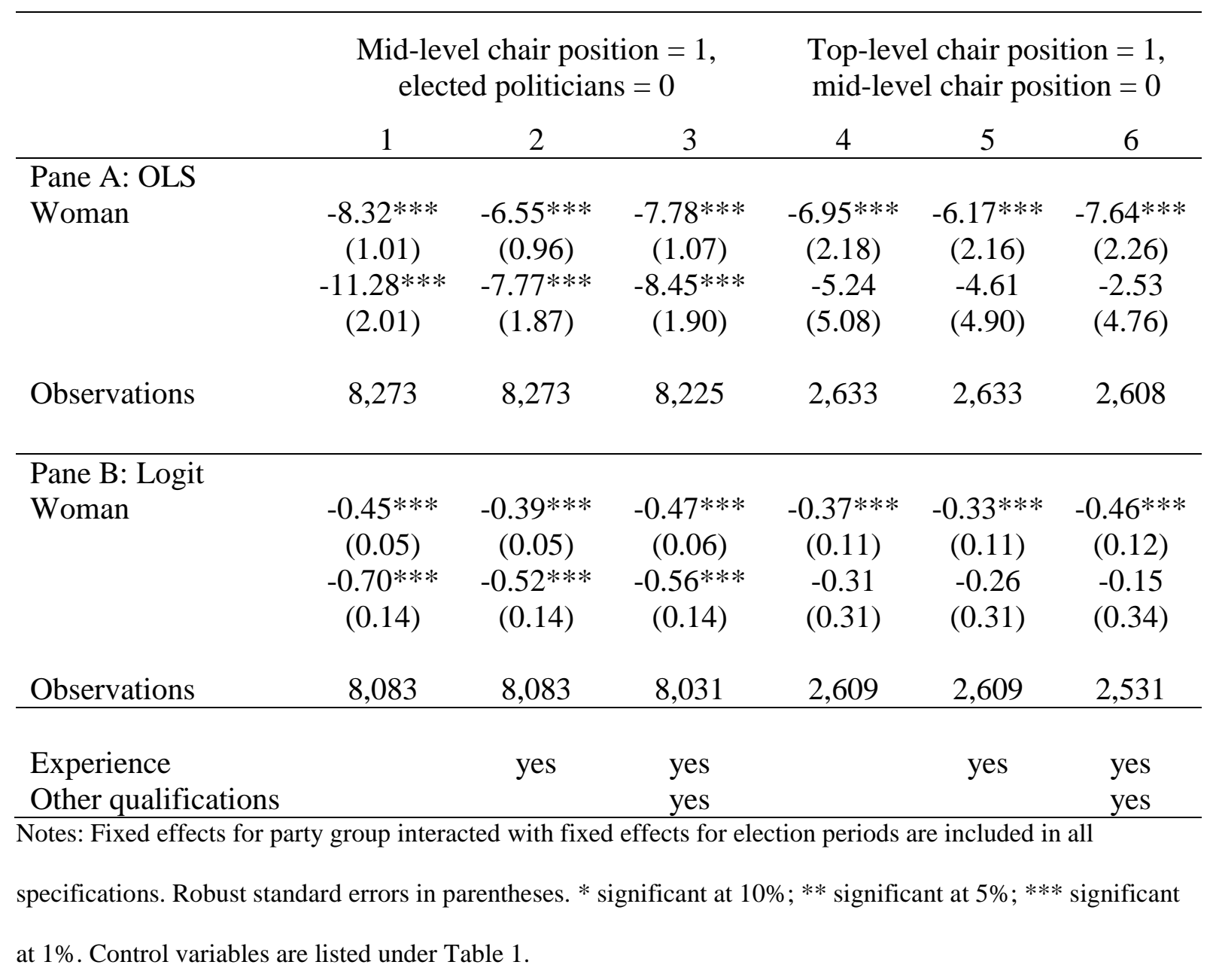


Table S.11. Gender inequality in transitions to positions of influence between 2006 and 2010.

Only first-generation immigrants included in minority definition.

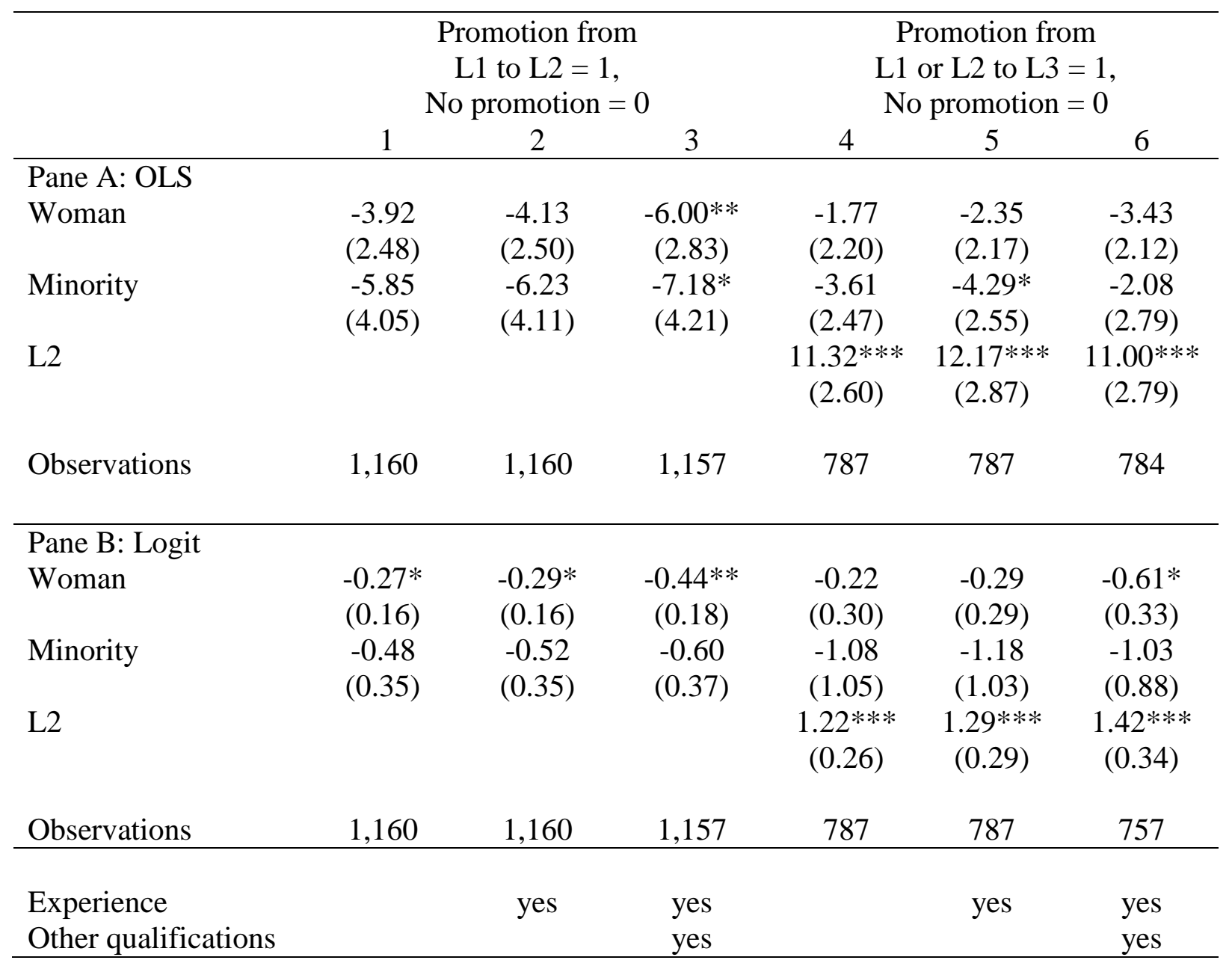

Notes: Fixed effects for party group interacted with fixed effects for election periods are included in all specifications. Robust standard errors in parentheses. * significant at 10\%; ** significant at 5\%; *** significant at 1\%. Control variables are listed under Table 1. 


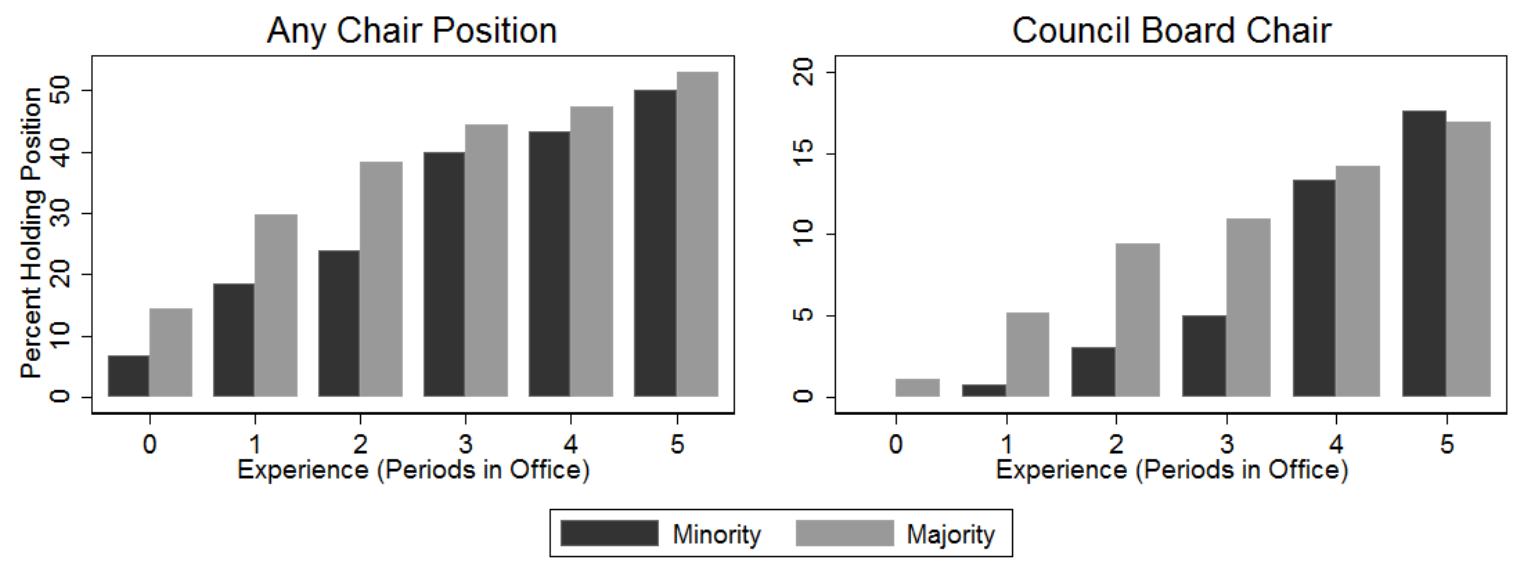

Figure S5. Gender (top) and racial (bottom) inequality in the proportion of individuals that holds influential positions by total tenure in elected office, pooled 2006 and 2010 data. Only firstgeneration immigrants are defined as minority politicians. 


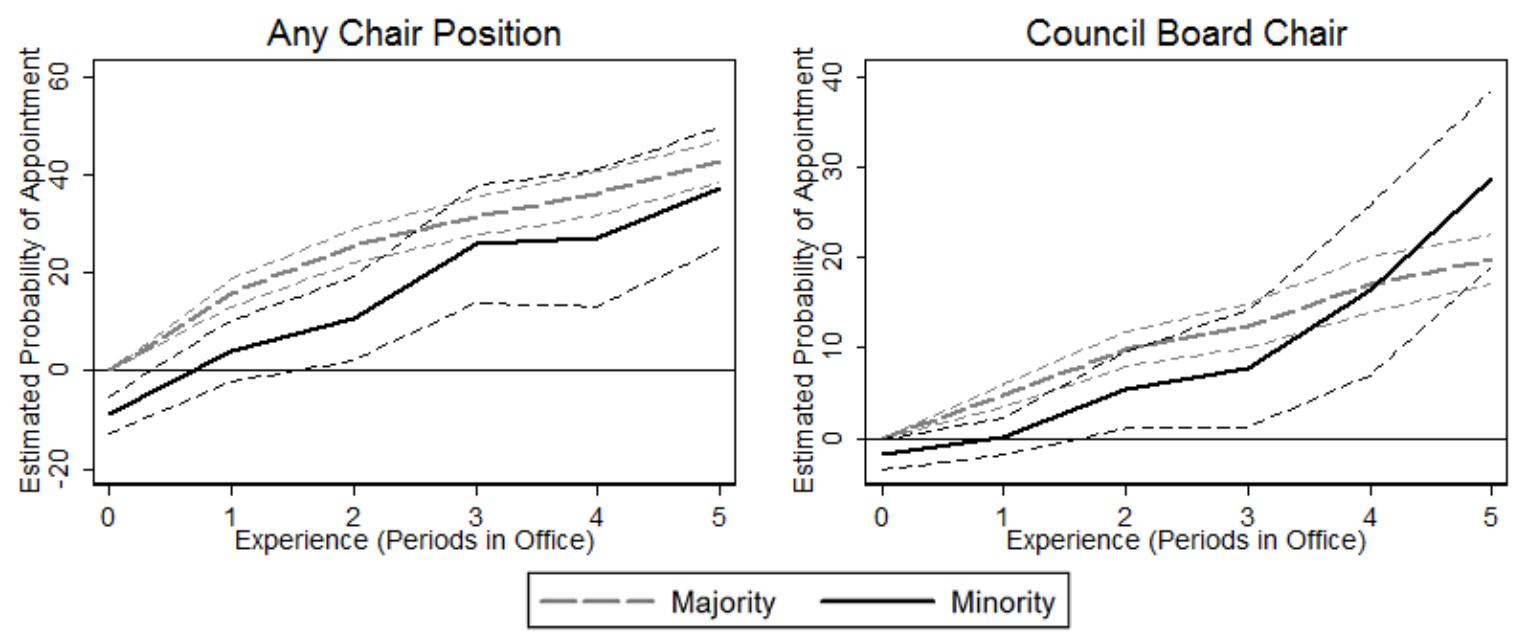

Figure S6. Estimated gender (top) and racial (bottom) inequality in the proportion of individuals that holds influential positions by total tenure in elected office, pooled 2006 and 2010 data. Only first-generation immigrants are defined as minority politicians. 


\section{References}

Baltrunaite, Audinga, Piera Bello, Allesandra Casarico, and Paola Profeta. 2012, "Gender

Quotas and the Quality of Politicians." Mimeo, Bocconi University.

Bækgaard, Martin, and Ulrik Kjaer. 2012. "The Gendered Division of Labor in Assignments to Political Committees: Discrimination or Self-Selection in Danish Local Politics?" Politics \& Gender 8 (4): 465-82.

Besley, Timothy, and Marta Reynal-Querol. 2011. "Do Democracies Select More Educated Leaders?." American Political Science Review 105 (3): 552-66.

Carroll, Susan. 2008. “Committee Assignments: Discrimination or Choice?” In Legislative Women: Getting Elected, Getting Ahead, ed. Beth Reingold. Boulder, CO: Lynne Rienner, 135-56.

Davis, Rebecca Howard. 1997. Women and Power in Parliamentary Democracies: Cabinet Appointments in Western Europe, 1968-1992. Lincoln: University of Nebraska Press.

De Paola, Maria, and Vincenzo Scoppa. 2011. "Political Competition and Politician Quality: Evidence from Italian Municipalities." Public Choice 148 (3-4): 547-59.

Esteve-Volart, Berta and Manuel Bagues. 2012. Are Women Pawns in the Political Game? Evidence from Elections to the Spanish Senate. Journal of Public Economics 96 (3-4): 387-99.

Ferraz, Claudio, and Frederico Finan. 2011. "Motivating Politicians: The Impacts of Monetary Incentives on Quality and Performance.” Mimeo, Berkeley University.

Franceschet, Susan, and Jennifer M. Piscopo. 2012. "Gender and Political Backgrounds in Argentina." In The Impact of Gender Quotas, ed. Drude Dahlerup, 43-56. 
Folke, Olle, Torsten Persson, and Johanna Rickne. 2014. "Preferential Voting, Accountability and Promotions into Political Power: Evidence from Sweden.” IFN Working Paper Series (No. 1002).

Galasso, Vincenzo, and Tommaso Nannicini. 2011. "Competing on Good Politicians." American Political Science Review 105(1): 79-99.

Gilljam, Mikael, David Karlsson, and Anders Sundell. 2010. Politik på hemmaplan. Tiotusen fullmäktige-ledamöter tycker om politik och demokrati. Stockholm: SKL Kommentus AB.

Lawless, Jennifer L., and Richard L. Fox. 2010. It Still Takes A Candidate: Why Women Don't Run for Office. New York: Cambridge University Press.

Messner, Matthias, and Mattias K. Polborn. 2004. "Paying politicians." Journal of Public Economics 88(12): 2423-2445.

Montin, Stig. 2007. Moderna kommuner. Malmö: Liber.

Norris, Pippa, and Joni Lovenduski. 1995. Political Recruitment: Gender, Race and Class in the British Parliament. Cambridge: Cambridge University Press.

Schwindt-Bayer, Leslie A. 2011. "Women who Win: Social Backgrounds, Paths to Power, and Political Ambition in Latin American Legislatures." Politics \& Gender 7 (1): 133.

Wide, Jessika, 2011. "Kvinnors vertikala marginalisering i kommunalpolitiken i Sverige." Mimeo, Umeå University.

Yule, Jean. 2000. “Women Councillors and Committee Recruitment.” Local Government Studies 26 (1): 31-54. 